\title{
THE
}

\section{State Sponsored Health Insurance and State Economic and Employment Growth}

\author{
Liam Malloy \\ University of Rhode Island, Imalloy@uri.edu \\ Shanna Pearson-Merkowitz \\ University of Rhode Island, shanna_pearson@uri.edu \\ Irwin Morris
}

Follow this and additional works at: https://digitalcommons.uri.edu/ecn_facpubs
The University of Rhode Island Faculty have made this article openly available.
Please let us know how Open Access to this research benefits you.

This is a pre-publication author manuscript of the final, published article.

Terms of Use

This article is made available under the terms and conditions applicable towards Open Access

Policy Articles, as set forth in our Terms of Use.

\section{Citation/Publisher Attribution}

Malloy, L. C., Pearson-Merkowitz, S. \& Morris, I. L. (2016), State-Sponsored Health Insurance and State Economic and Employment Growth. Politics and Policy, 44, 945-975. doi: 10.1111/polp.12176 Available: http://dx.doi.org/10.1111/polp.12176 


\title{
State Sponsored Health Insurance and State Economic and Employment
}

\author{
Growth \\ LIAM MALLOY \\ University of Maryland \\ SHANNA PEARSON-MERKOWITZ \\ University of Rhode Island \\ IRWIN MORRIS \\ University of Maryland
}

While there is a clear relationship between better health and better economic outcomes, the effects of increasing health insurance on the economy remain understudied. We employ two datasets, one on health insurance coverage in the contiguous 48 U.S. states and one for countries in the OECD, to model the effect of expanding health insurance on state and country economic and employment growth over the last two decades. We find that increased health insurance coverage of the working age population, especially through government programs like Medicaid, is associated with faster GDP and employment growth. However, we also find that these results may be contingent on controlling the per-enrollee cost of these programs. These findings are informative for future health insurance reforms both federally and in the U.S. States.

Keywords: Social Policy, State Sponsored Health Insurance, State and Local Politics, United States, OECD, State Economic Growth, State Employment, Health Care Sector, Medicaid, Affordable Care Act, GDP Growth.

\section{Related Articles:}

\section{Related Media:}

Si bien existe una clara relación entre una buena saludo y mejores oportunidades económicas, los efectos de los aumentos en los constos de los seguros de salud han sido poco estudiados. Usamos dos bases de datos, una de la cobertura de seguros de salud en 48 estados de los Estados Unidos y otra para países de la OCDE para modelar el efecto de costos crecientes en el empleo y crecimiento económico nacional y estatal, durante las últimas dos décadas. Los resultados muestran que los crecientes costos de seguro de salud para la población económicamente activa, especialmente a través de programas gubernamentales como Medicaid, se asocia con un mayor crecimiento del empleo y PIB. Sin embargo, también econtramos que estos resultados pueden variar si se toma en cuenta el costo por persona inscrita al programa. 
Estos resultados pueden informar futuras reformas de salud a nivel federal y estatal en los Estados Unidos.

Better overall health is associated with better macroeconomic performance for countries (see e.g., Murphy and Topel 2006). The cause of this relationship could be through innovation and productivity growth in the health care sector, or through the improvement in health of the labor force (or both). This, however, leaves open the question of whether or not extending health insurance coverage to a larger percentage of the population is good for economic growth. Covering more people may increase their health and allow them to enter the labor force or work more hours. Increased spending on health care could spur investment in innovative technologies. On the other hand, increased health insurance coverage, especially public coverage, may come at the cost of higher taxes that could slow economic growth (see e.g., Padovano and Galli 2007). In addition, increased health care spending may crowd out spending in other areas that could be more innovative, thus slowing growth (see e.g., Collins et al. 2012).

The question of whether and to what extent health insurance coverage is related to economic growth became highlighted in the debate over whether to pass the Affordable Care Act (ACA). In their efforts to gain support for the bill, the Obama administration argued that the decline in health insurance coverage had significant negative effects on aggregate public health and the degradation of public health has significant national economic consequences (Council of Economic Advisors 2009). Specifically, the administration argued that GDP would be 4 percent higher by 2030 because reduced health care spending has the potential to increase national savings and investment and better health outcomes can increase the labor supply and make workers more productive. (Council of Economic Advisors 2009, 6-9).

The literature supports the argument that better health increases labor supply and economic growth. Several studies suggest that increased health outcomes are "one of very few 
robust predictors of economic growth" (Suhrcke and Urban 2010). In one sense, the studies are clear: quality health insurance decreases the onset of avoidable illnesses, increases access to care for treatable illnesses, and can decrease the likelihood that relatively minor illnesses become severe - all of which decrease employment (see e.g., Bernstein, Chollet, and Peterson 2010). For example, not only has reducing the prevalence of particular conditions been shown to increase personal earnings by 15 to 20 percent, but poor health has also been found to be a primary reason people leave the workforce early (Hadley 2003) and file for social welfare programs, particularly disability for illnesses that could have been prevented had they had access to health insurance before their health problems worsened (Bernstein, Chollet, and Peterson 2010; Decker et al. 2012).

Research also suggests that health improvements that occurred since the 1970s added approximately 3.2 trillion dollars per year to national wealth in the United States or almost half of GDP (Murphy and Topel 2006). In addition, there is evidence that increased public spending on health care leads to increased health outcomes. Mays and Smith (2011) find that higher public health spending is associated with lower rates of preventable deaths such as infant mortality, diabetes, and cancer. In a review of the literature, Singh (2014) concludes that higher public health spending is associated with better community health, although the path from one to the other is not always clear. ${ }^{1}$

\footnotetext{
${ }^{1}$ The administration's claims about the economic growth - and cost-cutting - that would flow from the expansion of health care coverage have been extremely controversial. For example, a recent Congressional Budget Office (2015) report argues that repealing the ACA would actually increase economic growth. However, their argument appears to rely on the intensive margin of the labor supply decision. While repealing the ACA and its higher effective marginal taxes may increase the number of hours worked and economic growth, the analysis seems to ignore the extensive margin of the labor supply decision; that is, whether or not people enter the work force at all. If the ACA leads to higher labor force participation by creating a healthier potential work force, than the economic growth implications of the law (or its repeal) are unclear. Here, we do not investigate the economic effects of the ACA specifically.
} 
To address this important political and policy question, we estimate two models. The first model is a 48-state, multi-decade model of the impact of health care coverage (by type of provider) that also accounts for the costs associated with health care provision. The second model is a model of national-level economic growth that includes the OECD nations. Using these two datasets we are able to test our hypotheses using both state-level and national-level data over a series of decades. We also use an improved modeling strategy that accounts for the endogeneity present in all specifications of economic growth. Our analysis is the first analysis we have found that offers both an assessment of the impact of health insurance coverage on state and national-level economic growth and accounts for the cost to the state of providing health care. Our data end in 2010, just prior to the implementation of the Affordable Care Act (ACA). Thus, this research while not testing the provisions of the ACA, tests the basic premise of the arguments made during the debates over whether to pass and implement the ACA-the economic impact of increasing access to health insurance. We also are able to test the specific connection between state-provided (e.g., public) health insurance and economic growth, which has also been very controversial in the last few years as the ACA expanded access to Medicaid drastically but the "public option" argued by some in Congress was rejected.

We find that in both panels increased health insurance coverage is associated with faster economic growth. In the United States, we find evidence that Medicaid coverage increases both macroeconomic growth and employment growth. However, our results also suggest that in their efforts to capitalize on the economic benefits of expanding health insurance, legislators would be wise to implement policies that control per-enrollee costs. To the extent that the economic implications of increased state-supported health care coverage are a key aspect of the ongoing debate in the health insurance policy arena, our findings could inform future reforms. 


\section{Social Policy and Economic Growth}

Previous studies of the relationship between social policies and state economic growth find inconsistent effects (see e.g., Blair and Premus 1987; Crain and Lee 1999; Dye 1980; Erickson 1987; Fisher 1997; Helms 1985; Jiwattanakulpaisarn et al. 2009; Jones 1990; Jones and Vedlitz 1988; Newman 1983; Schneider 1987). Some find positive relationships between spending and economic growth, others a negative relationship, and still others find no relationship at all. ${ }^{2}$ Work on the specific relationship between health spending and economic growth is very limited. For example, a report issued by the Department of Health and Human Services $(2008,47)$ reviewing the literature on government health spending and economic growth concluded that "[g]iven that most of the literature in this area is based on anecdotal reports or descriptive evidence, there is significant scope for improving the current methods by using longitudinal data and more rigorous empirical analysis." Their own empirical tests using a panel dataset including 13 years of state spending data suggested a positive relationship between government expenditures on health and state economic growth, a result contrary to that found in Jones (1990).

Because health problems worsen when unaddressed, cities paying for emergency care of uninsured populations may pay significantly more for the health problems that result from putting off care than places that pay upfront for preventative care (Baicker and Chandra 2006 Baker, Fisher, and Wennberg 2008; Bamezai and Melnick 2006). In fact, Baicker and Chandra $(2004,184)$ find that spending and health outcomes are inversely related perhaps because "the use of intensive, costly care...crowds out the use of more effective care." Scholarship on the relationship between health care spending in health outcomes suggests a complex relationship.

\footnotetext{
${ }^{2}$ See Fisher (1997) for a thorough review.
} 
Fisher and others (2007) find that additional spending on Medicare patients tends to be associated with higher numbers of procedures rather than improved health outcomes. Other research suggests that health care spending does produce improved outcomes but only in particular populations (i.e., infants due to a decrease in infant mortality) (Gallet and Doucouliagos 2015). While the relationship between health care spending and health outcomes is complex, the relationship between spending on health insurance and health care outcomes may be more straightforward. Health insurance may lead to more desirable health care outcomes directly (through care which addresses extant diseases/infirmities) and indirectly (through preventative care), and healthcare spending is not a simple proxy for the prevalence of health care insurance (see Anderson and Frogner 2008; Anderson and Poullier 1999).

Over the last decade, there has been an increase in attention to assessing social programs to see if they "work." In the health care policy arena, these assessments tend to focus on one of two primary criteria: (1) health outcomes, or (2) fiscal efficiency. If health insurance is supposed to make people healthier, we can evaluate Medicaid (for example) based on the health related outcomes of program participants (e.g., Baiker et al. 2013). But states (and politicians) also have to weigh if a program is "worth the cost" given that there are other calls on the public purse. These assessments focus more on if a program saves more money than it spends over time or leads to economic growth that helps the state recoup its costs (in terms of making up lost or increasing tax revenue for example) or an increase in employment growth that makes the state economy stronger. If providing public health insurance strengthens the economy and reduces the net cost of the program, it should enjoy broader support. Policy experts disagree about the net costs of existing state-sponsored health insurance programs, the focal point of this article. Below, we review these arguments. 


\section{Pro: Expanding State Sponsored Health Insurance is Worth the Cost}

First, increasing access to health insurance could positively affect labor supply and demand. Access to health insurance increases the ability of people to remain in the workforce because it keeps them healthier and increases the likelihood that they will be available for work. While this can increase overall lifetime earnings and decrease employee turnover, it also could reduce the number of people reliant on other government social programs such as social security, food stamps, housing assistance, etc. Moreover, access to health insurance, particularly through the government may eliminate "job lock" and encourage entrepreneurial activities such as starting a new business or investing in research that could create more jobs for others (see e.g., Sterret, Bender, and Palmer 2014).

Likewise, larger government sponsored programs could alleviate some inequalities in the system (Sterret, Bender, and Palmer 2014). For example, under an employee-sponsored health insurance regime, firms with more elderly or disabled employees, pregnant women, and so on, pay more for health care than firms who have employees that are cheaper to cover. The financial incentives generated by this insurance regime may encourage firms to either discriminate against certain workers (American Civil Liberties Union 2002), decrease wages (Gruber 1994) and investments, or decrease hiring additional workers (especially new full time workers) (Baicker and Chandra 2006) as health care costs become a larger percentage of labor costs. For these reasons, increasing government sponsored health insurance could increase employment and economic growth by increasing the labor supply and eliminating market inefficiencies.

Looking specifically at Medicaid, some evidence suggests that expanding Medicaid coverage could increase economic and employment growth. Baiker and others (2013) harnessed 
the unique "experimental" expansion of Medicaid in Oregon to test how Medicaid coverage affected individual health outcome and economic security. While Medicaid access did not improve all health outcomes, "Medicaid coverage decreased the probability of a positive screening for depression, increased the use of many preventive services, and nearly eliminated catastrophic out-of-pocket medical expenditures" (Baiker et al. 2013). A related study demonstrated that those participating in the Medicaid expansion had "lower out-of-pocket medical expenditures and medical debt (including fewer bills sent to collection), and better selfreported physical and mental health than the control group" (Finkelstein et al. 2012). ${ }^{3}$

State-sponsored health insurance may boost economic growth through other means as well. Providing lower income individuals with state health insurance can increase tax revenues by keeping families and individuals out of debt that would otherwise keep them from paying their taxes. For example, as the cost of health care has increased in the United States, lack of health insurance has become the largest driver of bankruptcy (Himmelstein et al. 2009). Expenses associated with significant health issues also decrease the ability of families to invest in activities that would increase their economic position and thus increase taxable income. For example, a study by Collins and others (2012) found that 36 percent of young adults had medical debt, and of those 31 percent had put off education and career plans, 28 percent were unable to meet their basic financial obligations because of medical bills, and 32 percent could not make their student loan or tuition payments.

A third mechanism through which state sponsored health insurance could bolster economic growth is as a direct economic stimulus (see e.g., Pauly 2003): expenditures on health care increase both wages and the number of jobs in the health care sector. To the extent that

\footnotetext{
${ }^{3}$ However, studies also showed that Medicaid access increased the rate of emergency room visits even for illnesses that could have been dealt with in an outpatient setting (Taubman et al. 2014).
} 
expenditures on health care lead to new treatments and cures that decrease morbidity and infirmity, spending can result in a large financial gain for the country. (Aaron 2003; Murphy and Topel 2006).

\section{Con: Expanding State Sponsored Health Insurance is Not Worth the Cost}

However, there are also arguments that state-sponsored health insurance is bad for economic growth. For states, investing in state sponsored health insurance programs might be harmful because they come at the expense of other investments such as education and infrastructure (HHS 2008). For example, Kane, Orszag, and Guntner (2003) estimate that each new dollar spent on Medicaid results in a 6 or 7 cent cut in higher education appropriations. There are also economic arguments that because state sponsored health insurance programs are funded through taxes, that any expansion will be detrimental to economic and employment growth (Alesina and Perotti 1994).

Increased public health coverage, of course, also comes with a cost to taxpayers. If states are forced to raise marginal tax rates to pay for expanding coverage, this could lead to lower growth by decreasing the incentives to work. Padovano and Galli (2007), for example, find higher marginal tax rates are associated with lower growth in an OECD sample. This could potentially offset any positive economic benefits associated with increased health coverage, especially if public health care coverage is run inefficiently. An inefficient public health care sector will lead to higher costs per person, necessitating higher marginal tax rates, and potentially leading to lower economic growth (see e.g., Alesina and Rodrik 1994).

Medicaid, as a means-tested program, may have additional negative effects on economic and employment growth by actually discouraging (too much) work. Those who qualify for Medicaid may worry about losing benefits if they earn above the maximum income level, especially if their 
new jobs do not come with health insurance. This effectively increases the marginal tax rate faced by low-income workers. Holt and Romich (2007) following work by Shaviro (1999) find that low-income households can face marginal tax rates in excess of 50 percent as benefits like EITC and Medicaid phase out or disappear. Similarly, Yelowitz (1995) found that allowing children to stay on Medicaid when mothers earned more income led to an increased labor supply for some mothers.

The literature to date leaves us with an unclear picture about how increased access to health insurance and particularly increased state run health insurance should affect economic growth. Given the evidence to date presented above, we hypothesize that higher levels of health insurance coverage among the working age population, particularly state sponsored health insurance coverage, should increase economic growth but that increased spending per enrollee for government funded health insurance programs will have the opposite effect. Thus, we test the following two hypotheses:

H1: The Healthy Worker Hypothesis: Higher levels of health insurance among the working age population will lead to an increase in GDP and employment growth. H2: The Efficiency Hypothesis. Higher levels of per person spending will have a negative impact on both economic and employment growth.

\section{Data and Methods}

We have constructed two complementary data sets to test these hypotheses. The first is a panel of state-level observations for the United States that allows us to test the effects of health care coverage on economic growth within a single country. In addition, this dataset allows us to compare the differential impact of public and private healthcare coverage for different age groups on economic growth. While no state in the United States has a single payer system 
similar to that in several OECD countries, the U.S. states vary widely in how many people are covered by health insurance, particularly in regards to how many people are covered via statesponsored "public" programs (Medicare, Medicaid, or Military") versus private-market insurance. Second, we use a panel of OECD countries which allows us to estimate the effect of guaranteeing coverage for the entire population as several of the countries have universal health care systems. The U.S. state data spans the years 1988-2010 and the OECD data spans the years 2000-11 because of sporadic data availability. ${ }^{5}$ Both datasets also include spending data that allow us to test the hypothesis that the cost of health insurance can also affect economic growth.

One improvement upon the existing literature is that we employ a more appropriate methodology to deal with the endogeneity issues that are endemic to models of economic growth. The question of the contemporaneous effect of health insurance coverage on economic growth is complicated by the business cycle and potential endogeneity between economic growth and state spending. ${ }^{6}$ To address the business cycle issue, we incorporate a number of control variables, explained below. We also employ the Arellano-Bond (1991) generalized methods of moments (GMM) estimator to deal with potential endogeneity. ${ }^{7}$ Differencing the variables with

\footnotetext{
${ }^{4}$ While there are a number of other public health insurance plans (such as Indian Health Services and health care for prisoners), Medicare, Medicaid, and Military represent the vast majority of public health care spending.

${ }^{5}$ Both panel datasets are gathered from publicaly available aggregate (U.S. State-level or OECD Countrylevel) data sources.

${ }^{6}$ We have fewer data points available for our OECD sample when controlling for the business cycle. Fixed-effect regressions using a Hodrik-Prescott filter to remove business cycle effects gives us similar results with a larger sample size. We report the Arellano-Bond GMM results here to be consistent with our state-level results.

7 See Roodman (2009) for a how-to, and Prillaman and Meier (2014) for a current social science example). As Roodman $(2009,86)$ notes, Arellano-Bond is designed for models in which "1) "small T, large N" panels, meaning few time periods and many individuals; 2) a linear functional relationship; 3) one left-hand-side variable that is dynamic, depending on its own past realizations; 4) independent variables that are not strictly exogenous, meaning they are correlated with past and possibly current realizations of the error; 5) fixed individual effects; and 6) heteroskedasticity and autocorrelation within
} 
this method removes state/country fixed effects, and we use lagged variables as instrumental variables. In addition, we use population growth and a state-specific health care price index from the Bureau of Economic Analysis as exogenous instruments in the state data. ${ }^{8}$ Models run without GMM but that include state/country fixed effects result in findings that are substantively equivalent to those presented using GMM and are available upon request.

\section{United States Data}

In the case of the lower 48 states, the independent variables of interest are the percent of the population covered by health insurance, which we further break down by age (under 18 and 18-65), type (public vs. private plans), and subtype (specifically for public health insurance: Medicare vs. Medicaid vs. military benefits). ${ }^{9}$ Data on this variable span the years 1988 to 2010; however, not all control variables are available for all years. Nevertheless, all variables are available in equal number for each state so that the data set remains balanced just with a slightly smaller sample size.

First, to control for the business cycle we include the state unemployment rate and the employment to population ratio. ${ }^{10} \mathrm{We}$ also include national variables including the unemployment rate, a recession dummy (=1 in years in which the United States is in recession), and U.S. GDP per capita growth. ${ }^{11}$ Second, it is necessary to control for other causes of statelevel growth. To control for the potential differences in growth that come from different levels of

individuals but not across them." This description fits our model, with 30 years and 48 states, quite well, and addresses the potential endogeneity of our health insurance coverage variables.

${ }^{8}$ While neither are perfect instruments, both are more correlated with the main regressor variables (health insurance coverage by type and group) than with the dependent variable, growth in state GDP per capita.

9 Data on health insurance rates by state are available from the U.S. Census at: https://www.census.gov/hhes/www/hlthins/data/historical/.

${ }^{10}$ Unemployment by state was available from the Bureau of Labor Statistics at http://www.bls.gov/lau/

${ }^{11}$ Our primary measure of state economic growth was collected from the Bureau of Economic Analysis at the U.S. Department of Commerce. 
GDP per capita, we include the log of real GDP per capita. ${ }^{12} \mathrm{We}$ also include several variables to capture the business and economic climate of the state, including an index of "economic freedom" which captures such things as the level of regulatory burden on business, property rights, and price controls, which may distort the market (McMahon and Stansel 2013). ${ }^{13} \mathrm{We}$ control for the total state tax rate which might also impact economic growth, and we include state government spending broken down by category including capital expenditures and spending on education and health and hospitals. ${ }^{14}$ We use the percent of high school and college graduates to control for human capital levels. Finally we include a series of demographic controls that have historically been associated with health and economic status (Williams and Collins 1995) including the percent of the population in poverty, the percent black, the percent Hispanic, and age (under 18 and above 65 ). ${ }^{15}$ Summary statistics for the main variables of interest in the state panel data set are given in Table 1.

\section{[Table 1 about here]}

\section{OECD Analysis}

The second data set is an unbalanced panel of up to 28 OECD countries spanning the years 2000-11 with a maximum number of observations per country of 10 . We use real GDP per capita growth (with purchasing power parity dollars) and total employment growth as the dependent variables while the independent variable of interest is the percent of the population

\footnotetext{
${ }^{12}$ In our datasets, states with higher GDP per capita tend to experience higher growth implying that states with higher GDP per capita are likely to grow faster. On the other hand, the OECD countries with higher levels of GDP per capita experience slower growth as the poorer countries experience the more standard catch-up growth.

${ }^{13}$ Available at: https://www.fraserinstitute.org/content/dean-stansel

14 Available from the Government Finance Data from the U.S. Census available at: https://www.census.gov/govs/state/

${ }^{15}$ Human Capital and Demographic data were collected from the U.S. Census website, available at: https://www.census.gov/popest/data/index.html
} 
covered by total health insurance or by public and/or private health insurance. Unlike our U.S. data, the age breakdown for the coverage data was unavailable for the OECD. In addition, there are far fewer available observations for private vs. public health insurance coverage than for health insurance coverage in total. However, we do control for spending on healthcare, both in total and broken down by public vs. private.

The control variables in this dataset are similar to the first but vary slightly based on data availability. They include an economic freedom index (Gwartney, Lawson, and Hall 2013), capital formation as a percent of GDP (as a measure of investment), taxes as a percent of GDP, and the percent of the population under 15 and over 65, following the general outline of Barro (2000). All variables except for the economic freedom index come from OECD Stats website. ${ }^{16}$ Barro (2000) finds that investment is associated with higher growth while a larger government budget is negatively associated with growth. The economic freedom index controls for institutional factors that affect growth such as protection of property rights and regulation and trade restrictions. ${ }^{17}$

Summary statistics for the main variables of interest for the OECD data can be found in Table 2. Education data is available only in 5-year observations from Barro and Lee (2013) ${ }^{18}$ so as an additional control and as a check on our methodology, we present the OECD results using five year averages as well. ${ }^{19}$

\section{[Table 2 about here]}

\footnotetext{
${ }^{16}$ Data available from: http://stats.oecd.org/

17 The Economic Freedom Index was gathered from the Fraser Institute: http://www.freetheworld.com/reports.html

${ }^{18}$ Available at: https://idsc.iza.org/?page $=27 \& i d=150$

19 State variables are available for (almost) all years. Regressions using 5-year averages show no significant difference to the annual dataset
} 


\section{Results}

\section{Economic Growth and Health Insurance Rates in the U.S. States}

Table 3 presents the GMM regression results for the U.S. state panel dataset without spending. The main finding is that health insurance coverage for the working age population (1865 year olds) has a positive effect on economic growth. Column (i) shows that a 1 percentage point increase in coverage for the working age population is associated with an increase of 0.306 percentage points of contemporaneous annual growth. Column (ii) breaks out coverage by private vs. public healthcare plans and we can see that the positive effect is mainly due to public coverage (the coefficient on private coverage is positive but insignificant and much smaller). In column (iii) we break this out further to distinguish between Medicaid, Medicare, and Military coverage. They are all significant (at least at the 10 percent level) and of similar size, although military coverage appears to have the largest effect. This is not surprising given the federal spending that comes along with having a large military population in the state.

\section{[Table 3 about here]}

Coverage for those under 18 , who by and large are not in the workforce, is not significant and the economic effect is quite small in all three of these regressions. Keep in mind that these regressions only measure the contemporaneous effect of health insurance coverage on economic growth rather than the long-run effect that might be present in covering children who may grow up to be healthier and more productive workers. Unfortunately, our dataset is not long enough to capture these effects.

Our dataset also allows us to look at the effect of healthcare spending on economic growth. We have the data broken down by type (private spending, Medicare spending, and 
Medicaid spending) and as a percent of the states' GDP and on a per-enrollee basis. ${ }^{20}$ Increased spending on healthcare may drive economic growth, especially if healthcare is a driver of productivity growth. On the other hand, higher healthcare spending will decrease spending in other industries which may decrease growth if those other industries are more productive.

Our results, presented in Table 4, show that personal healthcare spending, whether measured as a percent of GDP (column (i)) or per capita (column (ii)) has a significant negative effect on growth. This implies that private healthcare spending, which was growing much faster than GDP in our sample, is a significant drag on growth. Government healthcare spending, on the other hand, has a positive effect on growth, especially Medicaid spending, although this is not always statistically significant.

\section{[Table 4 about here]}

Our regressions in Table 4 include health insurance coverage variables. These become insignificant in columns (i) and (ii) where private and government coverage are lumped together, but are (weakly) significant when we break out coverage by private vs. public in columns (iii) and (iv). Once again it is government coverage for the working age population that has a positive effect on contemporaneous economic growth. In column (v), which includes spending both as a percent of GDP and per capita (or per enrollee) costs, total Medicaid spending as a percent of GDP continues to have a positive effect on growth while personal healthcare spending as a

${ }^{20}$ These numbers have been converted from nominal to real using state-specific healthcare price indices reported by the Bureau of Economic Analysis. 
percent of GDP has a significantly negative effect. The per capita and per enrollee variables all have negative coefficients, but are not statistically significant. ${ }^{21}$

Another test that may help distinguish between the relative impacts of potential labor supply and healthcare innovation on growth is to use total employment growth ${ }^{22}$ as our dependent variable as opposed to economic growth. Table 5 repeats the regressions of Table 3 with employment growth as the dependent variable and health insurance coverage as the main independent variables of interest. These results mirror the earlier results with total coverage of the working age population, in column (i), increasing employment growth (while controlling for the employment to population ratio). Column (ii) shows that this is due to government coverage as opposed to private health insurance coverage, and column (iii) shows the effects are due equally to Medicaid and Medicare coverage. These results strongly imply that providing health coverage to this vulnerable population (mainly the poor, the disabled, and the working elderly) increases their labor supply significantly.

\section{[Table 5 about here]}

Table 6, which is similar to Table 4, adds healthcare spending to the independent variables. Total coverage of the working age population is now insignificant in columns (i) and (ii). In column (ii) private healthcare spending per capita has a significant positive effect on employment growth while increased Medicaid spending per enrollee has a significant negative effect on employment growth. These are the opposite signs from the results in Table 4. These results hold in columns (iii) - (iv) in which coverage is distinguished by type. Column (v) implies

\footnotetext{
${ }^{21}$ Our hypotheses do not include anything about the effect of insurance coverage as spending increases so we do not include an interaction term in these regressions. We expect the effects of coverage and spending to be independent. Regressions that include an interaction term return insignificant results.

${ }^{22}$ Results only looking at private-industry employment growth are very similar.
} 
that increased Medicaid coverage is positively associated with total employment growth but higher costs of the program have a mixed effect with total spending being associated with faster employment growth but higher spending per enrollee being associated with slower growth.

\section{[Table 6 about here]}

\section{Economic Growth and Health Insurance Rates in the OECD}

The results for the OECD panel are presented in Tables 7 and 8. While the OECD panel is unbalanced, it does allow us to test the effects of health insurance coverage at a national level. In all regressions, health insurance coverage is associated with higher economic growth. Column (i) looks at total health insurance coverage and healthcare spending. Increased coverage is (weakly) associated with higher GDP growth with a coefficient similar in size to those in the state-level regressions. Column (ii) breaks out coverage by public vs. private plans but finds that neither is significant. In this case, however, total healthcare spending is associated with slower economic growth. This result is unclear; however, as when we break out spending by source in column (iii), public spending appears to be positively associated by economic growth. This may be due to the diminished sample size and more recent timeframe or it is possible that the direction of causality runs in the other direction as faster growth (and higher tax revenue) leads to increased spending on health care.

\section{[Table 7 about here]}

Table 8 looks at the effects of health insurance coverage and healthcare spending on employment growth. Column (i) which looks at total coverage and total spending finds a weakly positive effect of both coverage and spending on growth. Column (iii), which highlights coverage and spending by type (public vs. private), also finds a positive effect of coverage on employment growth. While both public and private coverage are positive and significant, the 
effect of public coverage is about five times larger than for private coverage. Public healthcare spending is also weakly associated with higher employment growth, but private healthcare spending (which is often redundant in these countries with universal or near-universal coverage) is weakly associated with slower employment growth.

\section{[Table 8 about here]}

\section{Discussion and Conclusion}

This study employed two datasets - one on health insurance coverage in the contiguous 48 U.S. states and one for countries in the OECD - to model the effect of expanding health insurance on state and country economic and employment growth over the last two decades. We draw three main conclusions from our results. First, in the United States, government health insurance (e.g., Medicaid, Medicare, and Military) of the working age population is associated with faster GDP per capita growth. Second, health insurance coverage in general, but especially Medicaid coverage in the United States sample, and public coverage in the OECD sample, is associated with faster employment growth. Finally, in the United States, per-enrollee Medicaid spending is associated with slower GDP and employment growth. However, public healthcare spending in the OECD sample (and total Medicaid spending as a percent of state GDP) is associated with faster growth although the direction of causality is unclear. Taken as a whole our results suggest that when the government takes steps to insure a larger share of the working age population through government provided health insurance, it is beneficial to economic growth.

However, our results also suggest that a single-payer public healthcare system is likely to be the most beneficial for economic growth in that the government can maximize health insurance coverage and use its monopsony power as the only major buyer of health services to control costs. Single-payer systems have the benefit of covering the entire population (and 
therefore the entire working age population) and allow governments to set the rate for procedures, prescriptions, and other healthcare expenditures. This suggests that regardless of how the ACA specifically affects the economy, if the goal of health insurance regulators and reformers is to increase economic growth, they should reconsider a universal coverage public system. However, even as the ACA stands now, where many states have significantly expanded Medicaid to previously uncovered working age populations, our results do suggest that this should be beneficial to those states' economies.

\section{About the Authors}




\section{References}

Aaron, H. J. 2003. "Should Public Policy Seek To Control The Growth Of Health Care Spending?" Health Affairs (January 8). Accessed on January 31, 2015. Available online at http://content.healthaffairs.org/cgi/doi/10.1377/hlthaff.w3.28

Alesina, Alberro, and Roberto Perotti. 1994. "The Political Economy of Growth: A Critical Survey of the Recent Literature." The World Bank Economic Review 8 (3): 351-71. Accessed on June 29, 2016. Available online at http://documents.worldbank.org/curated/en/1994/09/441070/politicaleconomy-growth-critical-survey-recent-literature

AlesinA, AlberTo, and D. RoDRIK. 1994. "Distributive Politics and Economic Growth." The Quarterly Journal of Economics 109 (2): 465-90. Accessed on June 29, 2016. Available online at https://www.jstor.org/stable/2118470

AREllano, MANuel, and STEPHEN BOND. 1991. "Some tests of specification for panel data: Monte Carlo evidence and an application to employment equations." The Review of Economic Studies 58 (2): 277-297. Accessed on June 29, 2016. Available online at http://restud.oxfordjournals.org/content/58/2/277.short

AMERICAN CIVIL LIBERTIES UNION. 2002. Lifestyle Discrimination in the Workplace: Your Right to Privacy Under Attack. American Civil Liberties Union. Accessed on June 29, 2016. Available online at https://www.aclu.org/racial-justice_womens-rights/lifestyle-discrimination-workplaceyour-right-privacy-under-attack

Anderson, Gerald F., and Bianca K. Frogner. 2008. "Health Spending in OECD Countries: Obtaining Value Per Dollar." Health Affairs 27 (6): 1718-1727. Accessed on June 29, 2016. Available online at http://content.healthaffairs.org/content/27/6/1718.abstract

Anderson, Gerald F., and J.P. Poullier. 1999. "Health Spending, Access, and Outcomes: Trends in Industrialized Countries." Health Affairs 18 (3): 178-192. Accessed on June 29, 2016. Available online at http://content.healthaffairs.org/content/18/3/178.long

Baicker, Katherine, and Amitabh Chandra. 2004. "Medicare Spending, The Physician Workforce, And Beneficiaries' Quality Of Care." Health Affairs (April). Accessed on June 29, 2016. Available online at http://content.healthaffairs.org/cgi/doi/10.1377/hlthaff.w4.184

Baicker, Katherine, Sarah L. Taubman, Heidi L. Allen, Mira Bernstein, Jonathan H. Gruber, Joseph P. Newhouse, Eric C. Schneider, Bill J. Wright, Alan M. Zaslavsky, Amy N. FinKELSTEIN, and OREGON HEAlth STUdy GROUP. 2013. "The Oregon Experiment - Effects of Medicaid on Clinical Outcomes." New England Journal of Medicine 368 (18): 1713-22. Accessed on June 29, 2016. Available online at http://www.nejm.org/doi/full/10.1056/NEJMsa1212321\#t=article

BAicker, KAtherine, and AmitabH CHANDRA. 2006. "The Labor Market Effects of Rising Health Insurance Premiums." Journal of Labor Economics 24 (3): 609-634. 
Baker, Laurence. C., Elliot. S. Fisher, and John E. Wennberg. 2008. "Variations In Hospital Resource Use For Medicare And Privately Insured Populations In California." Health Affairs 27 (2): w123-34. Accessed on June 29, 2016. Available online at http://content.healthaffairs.org/content/27/2/w123.abstract

BAmeZAI, AnIL, and GlenN MelniCK. 2006. "Marginal Cost of Emergency Department Outpatient Visits: An Update Using California Data.” Medical Care 44 (9): 835-41. Accessed on June 29, 2016. Available online at ww.jstor.org/stable/41219528

BARRO, RoBert J. 2000. "Inequality and Growth in a Panel of Countries." Journal of Economic Growth 5: 5-32. Accessed on June 29, 2016. Available online at http://link.springer.com/article/10.1023\%2FA\%3A1009850119329

BARRO, RoberT J., and JONG WHA LEe. 2013. "A new data set of educational attainment in the world, 1950-2010.” Journal of Development Economics 104: 184-198. Accessed on June 29, 2016. Available online at http://www.sciencedirect.com/science/article/pii/S0304387812000855

Bernstein, Jill, Deborah Chollet, and Stephanie Peterson. 2010. How Does Insurance Coverage Improve Helath Outcomes? Mathematica Policy Research. Accessed on June 29, 2016. Available online at http://www.mathematica$\underline{\mathrm{mpr} . c o m / \sim / m e d i a / p u b l i c a t i o n s / P D F s / h e a l t h / r e f o r m h e a l t h c a r e ~ i b 1 . p d f ~}$

Blair, J. P., and R. Premus. 1987. "Major Factors in Industrial Location: A Review." Economic Development Quarterly 1 (1): 72-85. Accessed on June 29, 2016. Available online at http://edq.sagepub.com/content/1/1/72.abstract

Collins, Sara, Ruth Robertson, Tracy Garber, and Michelle Doty. 2012. Young, Uninsured, and in Debt: Why Young Adults Lack Health Insurance and How the Affordable Care Act Is Helping. New York, NY: Commonwealth Fund.

CONGRESSIONAL BUdGet OfFICE. 2015. "Budgetary and Economic Effects of Repealing the Affordable Care Act." Accessed on June 29, 2016. Available online at https://www.cbo.gov/sites/default/files/114th-congress-2015-2016/reports/50252-

Effects_of_ACA_Repeal.pdf

COUnCIL OF ECONOMIC AdVISERS. 2009. The Economic Case for Health Care Reform. Washington, D.C.: Executive Office of the President. Accessed on June 29, 2016. Available online at http://www.whitehouse.gov/assets/documents/CEA Health Care Report.pdf

Crain, W. MARK, and KATHERINe J. LeE. 1999. "Economic Growth Regressions for the American States: A Sensitivity Analysis.” Economic Inquiry 37 (2): 242-57. Accessed on June 29, 2016. Available online at http://onlinelibrary.wiley.com/doi/10.1111/j.14657295.1999.tb01428.x/abstract

Decker, SAndra L., JalPa A. Doshi, Amy E. Knaup, and Daniel Polsky. 2012. "Health Service Use Among the Previously Uninsured: Is Subsidized Health Insurance Enough?: Health Service Use 
Among the Previously Uninsured." Health Economics 21 (10): 1155-68. Accessed on June 29, 2016. Available online at http://www.ncbi.nlm.nih.gov/pubmed/22945812

Department of Health And Human Services. 2008. The Effect of Health Care Cost Growth on the U.S. Economy. Department of Health and Human Services. Accessed on June 29, 2016. Available online at http://aspe.hhs.gov/health/reports/08/healthcarecost/report.pdf

Dye, Thomas R. 1980. "Taxing, Spending, and Economic Growth in the American States." The Journal of Politics 42 (04): 1085. Accessed on June 29, 2016. Available online at http://journals.cambridge.org/action/displayAbstract?fromPage $=$ online $\&$ aid $=6220560$

ERICKSON, R. A. 1987. "Business Climate Studies: A Critical Evaluation.” Economic Development Quarterly 1 (1): 62-71. Accessed on June 29, 2016. Available online at http://edq.sagepub.com/content/1/1/62.short

Finkelstein, Amy, Sarah Taubman, Bill Wright, Mira Bernstein, Jonathan Gruber, Joseph P. Newhouse, Heidi Allen, Katherine Baicker, and Oregon Health Study Group. 2012. "The Oregon Health Insurance Experiment: Evidence from the First Year." The Quarterly Journal of Economics 127 (3): 1057-1106. Accessed on June 29, 2016. Available online at http://qje.oxfordjournals.org/content/early/2012/05/03/qje.qjs020.abstract

Fisher, Elliott, David GoOdman, JONATHan SkinNer, and Kristen BonNer. 2007. "Health Care Spending, Quality, and Outcomes." The Dartmouth Institute for Health Policy \& Clinical Practice.

FISHER, Ronald C. 1997. "The Effects of State and Local Public Services on Economic Development." New England Economic Review: 53-66.

Gallet, Craig A., and Hristos Doucouliagos. 2015. "The Impact of Healthcare Spending on Health Outcomes: A Meta-Regression Analysis.” Deakin University Economic Series 2015/11.

Gruber, Jonathan H. 1994. "The Incidence of Mandated Maternity Benefits." American Economic Review 84 (3). Accessed on June 29, 2016. Available online at http://www.ncbi.nlm.nih.gov/pubmed/10134748

GWartney, J., R. LAwson, and J. Hall. 2013. "Economic Freedom of the World 2013." American Enterprise Institute.

HADLEY, JACK. 2003. "Sicker and Poorer-The Consequences of Being Uninsured: A Review of the Research on the Relationship between Health Insurance, Medical Care Use, Health, Work, and Income." Medical Care Research and Review 60 (2): 3-75. Accessed on June 29, 2016. Available online at http://mcr.sagepub.com/content/60/2_suppl/3S.short?rss=1\&ssource=mfc

HELMS, L. JAY. 1985. "The Effect of State and Local Taxes on Economic Growth: A Time Series-Cross Section Approach." The Review of Economics and Statistics 67 (4): 574-82. Accessed on June 29, 2016. Available online at https://www.jstor.org/stable/1924801 


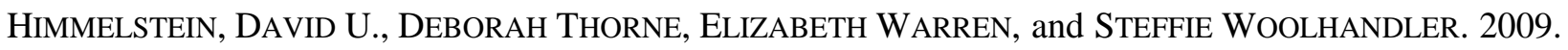
"Medical Bankruptcy in the United States, 2007: Results of a National Study." The American Journal of Medicine 122 (8): 741-46. Accessed on June 29, 2016. Available online at http://www.sciencedirect.com/science/article/pii/S0002934309004045

Holt, StePhen D., and Jennifer L. RoMich. 2007. "Marginal Tax Rates Facing Low- and ModerateIncome Workers Who Participate in Means-Tested Transfer Programs." National Tax Journal 60 (2): 253-76. Accessed on June 29, 2016. Available online at https://www.jstor.org/stable/41790387

Jiwattanakulpaisarn, Piyapong, Robert B. Noland, Daniel J. Graham, and John W. Polak. 2009. "Highway Infrastructure and State-Level Employment: A Causal Spatial Analysis." Papers in Regional Science 88 (1): 133-59. Accessed on June 29, 2016. Available online athttp://onlinelibrary.wiley.com/doi/10.1111/j.1435-5957.2008.00205.x/abstract

Jones, B. D., and A. VedLITZ. 1988. "Higher Education Policies and Economic Growth in the American States." Economic Development Quarterly 2 (1): 78-87. Accessed on June 29, 2016. Available online at http://edq.sagepub.com/content/2/1/78.abstract

JONES, BRYAN D. 1990. "Public Policies and Economic Growth in the American States." The Journal of Politics 52 (01): 219. Accessed on June 29, 2016. Available online at http://journals.cambridge.org/action/displayAbstract?fromPage $=$ online \&aid=6135112

KAISER FAMILY FOUNDATION. 2014. "Total Monthly Medicaid and Chip Enrollment." Available at: http://kff.org/health-reform/state-indicator/total-monthly-medicaid-and-chip-enrollment/. Visited on January 3, 2015. NOT CURRENTLY CITED IN MANUSCRIPT. OK TO DELETE FROM REF LIST?

Kane, Thomas J., Peter Orszag, and David L. Gunter. 2003. State Fiscal Constraints and Higher Education Spending: The Role of Medicaid and the Business Cycle. Washington, D.C.: The Urban Institute.

Mays, Glen P., and Sharla A. SMith. 2011. "Evidence Links Increases In Public Health Spending To Declines In Preventable Deaths." Health Affairs Accessed on June 29, 2016. Available online at http://content.healthaffairs.org/content/early/2011/07/19/hlthaff.2011.0196.full

McMahon, Fred, and DeAn StAnSEl. 2013. "Economic Freedom of North America 2013.” Fraser Institute.

MurPhy, Kevin, M., and Robert H. TOPEL. 2006. "The Value of Health and Longevity." Journal of Political Economy 114 (5): 871-904. Accessed on June 29, 2016. Available online at http://www.nber.org/papers/w11405

NESI, TED. 2014. “RI taxpayers face $\$ 52 \mathrm{M}$ tab for soaring Medicaid enrollment." WPRI.com. Available at: $\quad$ http://wpri.com/2014/04/29/ri-taxpayers-face-52m-tab-for-soaring-medicaid-enrollment/. Visited on January 3, 2015. NOT CURRENTLY CITED IN MANUSCRIPT. OK TO DELETE 
State Sponsored Health Insurance and Economic Growth

\section{FROM REF LIST?}

Newman, RoberT J. 1983. "Industry Migration and Growth in the South." The Review of Economics and Statistics 65 (1): 76-86. Accessed on June 29, 2016. Available online at www.jstor.org/stable/1924411

Padovano, F., and E Galli. 2007. "Tax Rates and Economic Growth in the OECD Countries." Economic Inquiry 39 (1): 44-57. Accessed on June 29, 2016. Available online at http://onlinelibrary.wiley.com/doi/10.1111/j.1465-7295.2001.tb00049.x/abstract

Peikes, Deborah, Greg Peterson, Randall S. Brown, SAndy GrafF, and John P. Lynch. 2012. "How changes in Washington University's Medicare coordinated care demonstration pilot ultimately achieved savings," Health Affairs, 31(6): 1216-1226. NOT CURRENTLY CITED IN MANUSCRIPT. OK TO DELETE FROM REF LIST?

PAuly, M. V. 2003. "Should We Be Worried About High Real Medical Spending Growth In The United States?" Health Affairs (January). Accessed on January 31, 2015. Available online at http://content.healthaffairs.org/cgi/doi/10.1377/hlthaff.w3.15

Prillaman, Soledad Artiz, and Kenneth J. Meier. 2014. "Taxes, Incentives, and Economic Growth: Assessing the Impact of Pro-business Taxes on U.S. State Economies." The Journal of Politics. 76 (2): 364-379. Accessed on June 29, 2016. Available online at http://papers.ssrn.com/sol3/papers.cfm?abstract_id=2107522

Roodman, D. (2014). xtabond2: Stata module to extend xtabond dynamic panel data estimator. Statistical Software Components.

SCHNEIDER, MARK. 1987. "Local Budgets and the Maximization of Local Property Wealth in the System of Suburban Government." The Journal of Politics 49 (04): 1104-16. Accessed on June 29, 2016. Available online

at http://journals.cambridge.org/action/displayAbstract?fromPage $=$ online $\&$ aid $=6262728$

SHAVIRO, DANIEL. 1999. "Effective Marginal Tax Rates on Low-Income Households." Employment Policies Institute. February. Accessed on Feb 4, 2015. Available online at https://www.epionline.org/wp-content/studies/shaviro_02-1999.pdf

Singh, Simone R. 2014. "Public Health Spending and Population Health: A Systematic Review." American Journal of Preventive Medicine 47 (5): 634-640. Accessed on June 29, 2016. Available online at http://www.sciencedirect.com/science/article/pii/S0749379714002359

Sterret, DAvid, Ashley Bender, and DAVID PAlmer. 2014. "A Business Case for Universal Healthcare: Improving Economic Growth and Reducing Unemployment by Providing Access for All." Health Law and Policy Brief 8 (2): 41-55.

SuHRCKe, MARC, and DiETER URBAN. 2010. "Are Cardiovascular Diseases Bad for Economic Growth?" Health Economics 19 (12): 1478-96. Accessed on June 29, 2016. Available online at 
http://www.ncbi.nlm.nih.gov/pubmed/19998332

Taubman, Sarah L., Heidi L. Allen, Bill J. Wright, Katherine Baicker, and Amy N. FINKELSTEIN. 2014. "Medicaid Increases Emergency-Department Use: Evidence from Oregon's Health Insurance Experiment." Science 343 (6168): 263-268. Accessed on June 29, 2016. Available online at http://science.sciencemag.org/content/343/6168/263

Wilkerson, John. 2003. "The Political Economy of Health in the United States." Annual Review of Political Science 6(1): 327-43. NOT CURRENTLY CITED IN MANUSCRIPT. OK TO DELETE FROM REF LIST?

Williams, DAVID R., and ChIQUITA Collins. 1995. "US Socioeconomic and Racial Differences in Health: Patterns and Explanations." Annual Review of Sociology 21: 349-386. Accessed on June 29 , 2016. Available online at http://www.annualreviews.org/doi/abs/10.1146/annurev.so.21.080195.002025

Yelowitz, A. S. 1995. "The Medicaid Notch, Labor Supply, and Welfare Participation: Evidence from Eligibility Expansions.” The Quarterly Journal of Economics 110 (4): 909-39. Accessed on June 29, 2016. Available online at http://qje.oxfordjournals.org/content/110/4/909.abstract 
Table 1: State-Level Summary Statistics

\begin{tabular}{|c|c|c|c|c|}
\hline Variable & Median & St. Dev. & $25^{\text {th }}$ Percentile & $7^{\text {th }}$ Percentile \\
\hline Real GDP per capita growth & 1.81 & 1.08 & 1.04 & 2.47 \\
\hline $\begin{array}{l}<18 \text { healthcare coverage } \\
\text { (private or public) }\end{array}$ & 89.8 & 4.7 & 86.0 & 92.2 \\
\hline $\begin{array}{c}<18 \text { healthcare coverage } \\
\text { (private) }\end{array}$ & 70.5 & 8.4 & 63.5 & 75.6 \\
\hline - Employee benefits & 63.6 & 7.9 & 57.6 & 68.7 \\
\hline - Direct purchase & 5.5 & 2.5 & 4.1 & 7.2 \\
\hline $\begin{array}{l}<18 \text { healthcare coverage } \\
\text { (public) }\end{array}$ & 25.4 & 8.2 & 20 & 31.2 \\
\hline - Medicare & 0.4 & 5.7 & 0.1 & 0.8 \\
\hline - Medicaid & 21.2 & 8.4 & 16.0 & 27.5 \\
\hline - Military & 3.0 & 2.4 & 1.9 & 4.9 \\
\hline $\begin{array}{l}\text { 18-65 healthcare coverage } \\
\text { (public of private) }\end{array}$ & 83.1 & 4.8 & 79.2 & 86.0 \\
\hline $\begin{array}{c}\text { 18-65 healthcare coverage } \\
\text { (private) }\end{array}$ & 74.7 & 6.13 & 69.5 & 78.4 \\
\hline - Employee benefits & 66.2 & 6.1 & 61.6 & 70.4 \\
\hline - Direct purchase & 7.6 & 2.6 & 6.3 & 9.3 \\
\hline $\begin{array}{l}\text { 18-65 healthcare coverage } \\
\text { (public) }\end{array}$ & 12.4 & 3.4 & 10.3 & 14.8 \\
\hline - Medicare & 2.7 & 2.8 & 2.0 & 3.6 \\
\hline - Medicaid & 6.5 & 3.7 & 5.0 & 8.6 \\
\hline- Military & 3.7 & 2.0 & 2.3 & 5.4 \\
\hline $\begin{array}{l}\text { Private Healthcare Spending } \\
(\% \text { of GDP) }\end{array}$ & 12.7 & 2.4 & 11.3 & 14.4 \\
\hline $\begin{array}{l}\text { Medicare Spending ( } \% \text { of } \\
\text { GDP) }\end{array}$ & 2.3 & 0.8 & 1.9 & 2.9 \\
\hline $\begin{array}{l}\text { Medicaid Spending ( } \% \text { of } \\
\text { GDP) }\end{array}$ & 1.8 & 0.7 & 1.5 & 2.2 \\
\hline $\begin{array}{l}\text { Private Healthcare spending } \\
\text { per capita }\end{array}$ & $\$ 5,600$ & $\$ 1,050$ & $\$ 4,900$ & $\$ 6,400$ \\
\hline $\begin{array}{l}\text { Medicare Spending per } \\
\text { enrollee }\end{array}$ & $\$ 7,300$ & $\$ 1,500$ & $\$ 6,300$ & $\$ 8,500$ \\
\hline $\begin{array}{l}\text { Medicaid Spending per } \\
\text { enrollee }\end{array}$ & $\$ 7,000$ & $\$ 2,100$ & $\$ 5,900$ & $\$ 8,400$ \\
\hline
\end{tabular}


Table 2: OECD-Level Summary Statistics

\begin{tabular}{|c|c|c|c|c|}
\hline Variable & Median & St. Dev. & $\begin{array}{c}25^{\text {th }} \\
\text { Percentile }\end{array}$ & $\begin{array}{c}7^{\text {th }} \\
\text { Percentile }\end{array}$ \\
\hline Real GDP per capita growth (\%) & 2.09 & 1.67 & 1.37 & 3.05 \\
\hline $\begin{array}{l}\text { Healthcare coverage (public or private, } \\
\% \text { of population) }\end{array}$ & 100 & 15.1 & 95.3 & 100 \\
\hline $\begin{array}{l}\text { - Public healthcare coverage (\% } \\
\text { of population) }\end{array}$ & 100 & 16.5 & 95.0 & 100 \\
\hline $\begin{array}{l}\text { - Private healthcare coverage } \\
\text { (\% of population) }\end{array}$ & 17.2 & 29.0 & 0.3 & 50.8 \\
\hline $\begin{array}{l}\text { Total healthcare expense (percent of } \\
\text { GDP) }\end{array}$ & 7.2 & 5.1 & 5.7 & 8.5 \\
\hline $\begin{array}{l}\text { - Public healthcare expense } \\
\text { (percent of GDP) }\end{array}$ & 5.1 & 2.3 & 3.7 & 6.4 \\
\hline $\begin{array}{l}\text { - Private healthcare expense } \\
\text { (percent of GDP) }\end{array}$ & 1.8 & 1.3 & 1.3 & 2.5 \\
\hline
\end{tabular}


Table 3: Effects of Health Insurance Coverage on State GDP Growth (U.S. States, 1988-2010) Dependent Variable $=$ State Real GDP per capita Growth

Health Insurance Coverage $<18$

$$
\begin{gathered}
-0.0249 \\
(0.0790) \\
0.306^{* * *} \\
(0.114)
\end{gathered}
$$

Health Insurance Coverage 18-65

Private Coverage $<18$

Government Coverage $<18$

Private Coverage 18-65

(ii)
(iii)

Government Coverage 18-65

$\begin{array}{cc}0.00958 & -0.0124 \\ (0.0697) & (0.0606) \\ -0.0818 & -0.00371 \\ (0.0636) & (0.0579) \\ 0.141 & 0.118 \\ (0.108) & (0.0726) \\ 0.491 * * * & \end{array}$

Medicaid Coverage 18-65

$(0.120)$

Medicare Coverage 18-65

$0.221 *$

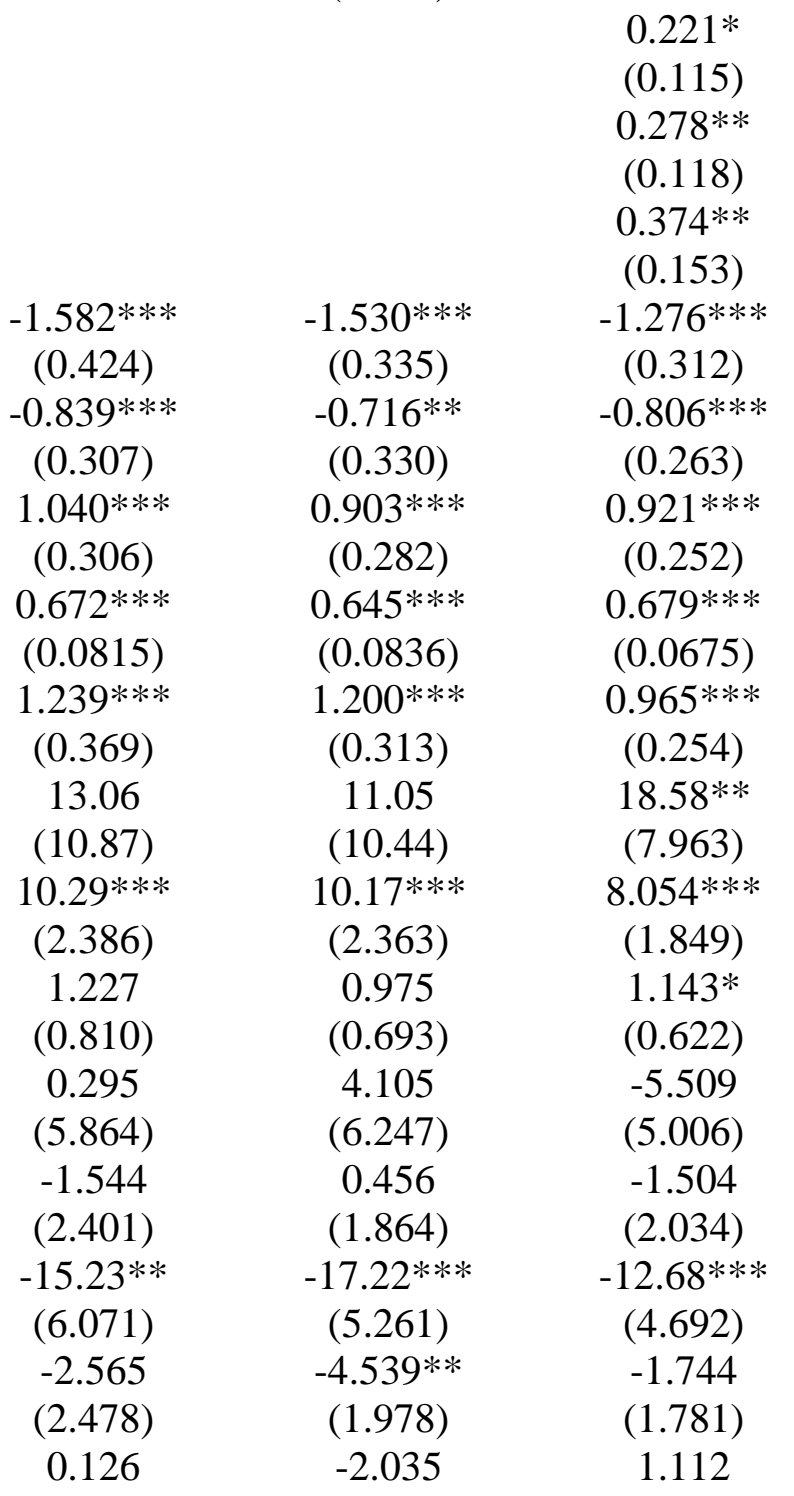

(Log) State Highway Spending 


\begin{tabular}{lccc} 
& $(2.210)$ & $(1.872)$ & $(2.023)$ \\
(Log) State Police \& Fire Spending & -2.545 & $-3.629 * *$ & $-2.956^{* *}$ \\
State Poverty Rate & $(2.080)$ & $(1.769)$ & $(1.483)$ \\
State Black Population (\%) & 0.293 & 0.0500 & 0.00838 \\
& $(0.194)$ & $(0.172)$ & $(0.140)$ \\
State Hispanic Population (\%) & 0.381 & 0.344 & 0.391 \\
& $(0.294)$ & $(0.312)$ & $(0.258)$ \\
State High School Grads (\%) & -0.197 & -0.0498 & -0.345 \\
& $(0.370)$ & $(0.380)$ & $(0.326)$ \\
State College Grads (\%) & $0.470 * * *$ & $0.363 * *$ & $0.288^{* *}$ \\
& $(0.171)$ & $(0.150)$ & $(0.120)$ \\
State Population > 65 (\%) & -0.178 & -0.150 & -0.0952 \\
& $(0.147)$ & $(0.131)$ & $(0.100)$ \\
State Population < 18 (\%) & -0.138 & -0.0545 & -0.0286 \\
& $(0.169)$ & $(0.131)$ & $(0.115)$ \\
GDP per capita growth (first lag) & 0.0111 & 0.0232 & 0.145 \\
& $(0.231)$ & $(0.168)$ & $(0.148)$ \\
GDP per capita growth (second lag) & $-0.507 * * *$ & $-0.508 * * *$ & $-0.455^{* * *}$ \\
& $(0.0546)$ & $(0.0533)$ & $(0.0507)$ \\
Observations & $-0.376^{* * *}$ & $-0.375 * * *$ & $-0.343 * * *$ \\
Number of state & $(0.0375)$ & $(0.0400)$ & $(0.0329)$ \\
\hline
\end{tabular}

Robust standard errors in parentheses

$* * * \mathrm{p}<0.01, * * \mathrm{p}<0.05, * \mathrm{p}<0.1$ 


\begin{tabular}{|c|c|c|c|c|c|}
\hline \multirow[b]{2}{*}{ Health Insurance Coverage $<18$} & (i) & (ii) & (iii) & (iv) & (v) \\
\hline & $\begin{array}{l}0.0576 \\
(0.0738)\end{array}$ & $\begin{array}{c}0.0988 \\
(0.0859)\end{array}$ & & & \\
\hline Health Insurance Coverage 18-65 & $\begin{array}{c}0.113 \\
(0.0891)\end{array}$ & $\begin{array}{l}0.0851 \\
(0.107)\end{array}$ & & & \\
\hline Private Coverage $<18$ & & & $\begin{array}{c}0.0220 \\
(0.0441)\end{array}$ & $\begin{array}{c}0.0352 \\
(0.0390)\end{array}$ & $\begin{array}{c}0.0257 \\
(0.0391)\end{array}$ \\
\hline Government Coverage $<18$ & & & $\begin{array}{l}-0.0104 \\
(0.0429)\end{array}$ & $\begin{array}{c}0.0214 \\
(0.0455)\end{array}$ & $\begin{array}{l}-0.0283 \\
(0.0374)\end{array}$ \\
\hline Private Coverage $18-65$ & & & $\begin{array}{l}-0.0413 \\
(0.0519)\end{array}$ & $\begin{array}{l}-0.0435 \\
(0.0498)\end{array}$ & $\begin{array}{l}-0.0364 \\
(0.0456)\end{array}$ \\
\hline Government Coverage 18-65 & & & $\begin{array}{l}0.159 * \\
(0.0965)\end{array}$ & $\begin{array}{c}0.164 * \\
(0.0950)\end{array}$ & $\begin{array}{c}0.130 \\
(0.0935)\end{array}$ \\
\hline \multirow[t]{2}{*}{$\begin{array}{l}\text { Personal Healthcare Spending ( } \% \\
\text { GDP) }\end{array}$} & $-1.548 * * *$ & & $-1.519 * * *$ & & $-1.327 * * *$ \\
\hline & $(0.475)$ & & $(0.423)$ & & $(0.510)$ \\
\hline Medicare Spending (\% GDP) & $\begin{array}{l}1.715 * * \\
(0.700)\end{array}$ & & $\begin{array}{l}1.329 * * \\
(0.641)\end{array}$ & & $\begin{array}{c}2.630 \\
(1.750)\end{array}$ \\
\hline Medicaid Spending (\% GDP) & $\begin{array}{l}5.217 * * * \\
(0.746)\end{array}$ & & $\begin{array}{l}3.193 * * * \\
(0.968)\end{array}$ & & $\begin{array}{l}2.801 * * * \\
(1.048)\end{array}$ \\
\hline \multirow[t]{2}{*}{$\begin{array}{l}\text { (Log) Real Personal Spending per } \\
\text { capita }\end{array}$} & & $-15.16^{* * *}$ & & $-15.18 * * *$ & -2.560 \\
\hline & & $(4.660)$ & & $(5.196)$ & $(6.289)$ \\
\hline \multirow[t]{2}{*}{$\begin{array}{l}\text { (Log) Real Medicare Spending per } \\
\text { enrollee }\end{array}$} & & 1.714 & & 1.814 & -5.545 \\
\hline & & $(2.801)$ & & $(2.105)$ & $(5.722)$ \\
\hline \multirow[t]{2}{*}{$\begin{array}{l}\text { (Log) Real Medicaid Spending per } \\
\text { enrollee }\end{array}$} & & $4.150 * *$ & & 2.334 & -1.173 \\
\hline & & $(2.068)$ & & $(1.526)$ & $(2.052)$ \\
\hline State Unemployment Rate & $\begin{array}{c}-1.027 * * * \\
(0.277)\end{array}$ & $\begin{array}{c}-1.349 * * * \\
(0.302)\end{array}$ & $\begin{array}{c}-1.060 * * * \\
(0.189)\end{array}$ & $\begin{array}{l}-1.229 * * * \\
(0.203)\end{array}$ & $\begin{array}{c}-1.083 * * * \\
(0.181)\end{array}$ \\
\hline Employment/Population Ratio & $\begin{array}{c}-1.286^{* * * *} \\
(0.311)\end{array}$ & $\begin{array}{c}-0.830 * * * \\
(0.264)\end{array}$ & $\begin{array}{c}-0.781 * * * \\
(0.214)\end{array}$ & $\begin{array}{l}-0.894 * * * \\
(0.240)\end{array}$ & $\begin{array}{c}-0.726^{* * * *} \\
(0.199)\end{array}$ \\
\hline US Recession Dummy & $\begin{array}{c}0.314 \\
(0.287)\end{array}$ & $\begin{array}{l}0.426^{*} \\
(0.247)\end{array}$ & $\begin{array}{c}0.316 \\
(0.235)\end{array}$ & $\begin{array}{l}0.428^{*} \\
(0.241)\end{array}$ & $\begin{array}{c}0.298 \\
(0.226)\end{array}$ \\
\hline US GDP per capita growth rate & $\begin{array}{l}0.537 * * * \\
(0.0863)\end{array}$ & $\begin{array}{c}0.564 * * * \\
(0.0708)\end{array}$ & $\begin{array}{l}0.569 * * * \\
(0.0629)\end{array}$ & $\begin{array}{c}0.606^{* * *} \\
(0.0698)\end{array}$ & $\begin{array}{l}0.546 * * * \\
(0.0636)\end{array}$ \\
\hline US Unemployment Rate & $\begin{array}{l}0.0728 \\
(0.280)\end{array}$ & $\begin{array}{c}0.779 * * * \\
(0.269)\end{array}$ & $\begin{array}{c}0.537 * * * \\
(0.181)\end{array}$ & $\begin{array}{l}0.549 * * \\
(0.227)\end{array}$ & $\begin{array}{c}0.503 * * \\
(0.200)\end{array}$ \\
\hline (Log) State GDP per capita & $\begin{array}{c}30.98 * * * \\
(5.433)\end{array}$ & $\begin{array}{c}22.24 * * \\
(9.203)\end{array}$ & $\begin{array}{c}22.11 * * * \\
(5.541)\end{array}$ & $\begin{array}{l}23.77 * * * \\
(6.239)\end{array}$ & $\begin{array}{c}25.75 * * * \\
(5.975)\end{array}$ \\
\hline Economic Freedom Index & $\begin{array}{c}2.347 \\
(1.574)\end{array}$ & $\begin{array}{c}7.406 * * * \\
(1.683)\end{array}$ & $\begin{array}{c}2.716^{* * *} \\
(1.118)\end{array}$ & $\begin{array}{c}4.314 * * * \\
(1.050)\end{array}$ & $\begin{array}{c}3.092 * * * \\
(1.144)\end{array}$ \\
\hline Average State Tax Rate & $\begin{array}{l}1.351^{*} \\
(0.763)\end{array}$ & $\begin{array}{c}2.458 * * * \\
(0.806)\end{array}$ & $\begin{array}{c}0.947 * * \\
(0.457)\end{array}$ & $\begin{array}{c}1.485^{* * * *} \\
(0.565)\end{array}$ & $\begin{array}{c}1.367 * * * \\
(0.458)\end{array}$ \\
\hline (Log) State Total Spending & $\begin{array}{c}-16.61 * * * \\
(5.645)\end{array}$ & $\begin{array}{c}-3.411 \\
(4.747)\end{array}$ & $\begin{array}{c}-8.481 * \\
(4.679)\end{array}$ & $\begin{array}{c}-2.981 \\
(4.447)\end{array}$ & $\begin{array}{c}-7.274 * \\
(4.283)\end{array}$ \\
\hline
\end{tabular}


State Sponsored Health Insurance and Economic Growth

\begin{tabular}{|c|c|c|c|c|c|}
\hline (Log) State Capital Spending & $\begin{array}{c}0.349 \\
(1.643)\end{array}$ & $\begin{array}{c}0.343 \\
(1.945)\end{array}$ & $\begin{array}{c}1.114 \\
(0.911)\end{array}$ & $\begin{array}{c}0.943 \\
(0.978)\end{array}$ & $\begin{array}{c}0.967 \\
(0.960)\end{array}$ \\
\hline (Log) State Education Spending & $\begin{array}{l}-8.060 * \\
(4.541)\end{array}$ & $\begin{array}{c}-10.81 * * * \\
(3.990)\end{array}$ & $\begin{array}{c}-7.158 * * * \\
(2.343)\end{array}$ & $\begin{array}{c}-6.275 * * \\
(2.747)\end{array}$ & $\begin{array}{c}-6.036^{* *} \\
(2.477)\end{array}$ \\
\hline (Log) State Health and Hosp. Spending & $\begin{array}{l}1.681 \\
(1.657)\end{array}$ & $\begin{array}{l}-1.281 \\
(1.687)\end{array}$ & $\begin{array}{l}-0.675 \\
(0.959)\end{array}$ & $\begin{array}{c}-0.620 \\
(1.008)\end{array}$ & $\begin{array}{l}-0.594 \\
(0.927)\end{array}$ \\
\hline (Log) State Highway Spending & $\begin{array}{c}1.737 \\
(1.957)\end{array}$ & $\begin{array}{l}0.0354 \\
(1.927)\end{array}$ & $\begin{array}{c}-0.0594 \\
(1.131)\end{array}$ & $\begin{array}{l}-0.727 \\
(1.186)\end{array}$ & $\begin{array}{l}-0.189 \\
(1.170)\end{array}$ \\
\hline (Log) State Police \& Fire Spending & $\begin{array}{l}-1.673 \\
(1.346)\end{array}$ & $\begin{array}{l}-3.054 * \\
(1.658)\end{array}$ & $\begin{array}{l}-0.992 \\
(0.775)\end{array}$ & $\begin{array}{l}-1.633^{*} \\
(0.833)\end{array}$ & $\begin{array}{l}-0.831 \\
(0.734)\end{array}$ \\
\hline State Poverty Rate & $\begin{array}{c}0.145 \\
(0.128)\end{array}$ & $\begin{array}{l}0.263 * \\
(0.151)\end{array}$ & $\begin{array}{l}-0.0619 \\
(0.0735)\end{array}$ & $\begin{array}{l}-0.0486 \\
(0.0721)\end{array}$ & $\begin{array}{c}0.0424 \\
(0.0722)\end{array}$ \\
\hline State Black Population (\%) & $\begin{array}{c}0.549 * * \\
(0.267)\end{array}$ & $\begin{array}{c}0.561 * * \\
(0.251)\end{array}$ & $\begin{array}{l}0.329 * \\
(0.179)\end{array}$ & $\begin{array}{c}0.357 * * \\
(0.177)\end{array}$ & $\begin{array}{l}0.353^{*} \\
(0.186)\end{array}$ \\
\hline State Hispanic Population (\%) & $\begin{array}{c}-0.811 * * * \\
(0.291)\end{array}$ & $\begin{array}{c}-0.00156 \\
(0.296)\end{array}$ & $\begin{array}{c}-0.468 * * * \\
(0.181)\end{array}$ & $\begin{array}{c}-0.336^{*} \\
(0.186)\end{array}$ & $\begin{array}{c}-0.413 * * \\
(0.165)\end{array}$ \\
\hline State High School Grads (\%) & $\begin{array}{l}0.0460 \\
(0.114)\end{array}$ & $\begin{array}{l}0.202^{*} \\
(0.120)\end{array}$ & $\begin{array}{c}-0.00688 \\
(0.0817)\end{array}$ & $\begin{array}{l}0.00213 \\
(0.0888)\end{array}$ & $\begin{array}{l}-0.0722 \\
(0.0855)\end{array}$ \\
\hline State College Grads (\%) & $\begin{array}{c}-0.0313 \\
(0.131)\end{array}$ & $\begin{array}{l}0.0526 \\
(0.130)\end{array}$ & $\begin{array}{l}-0.0239 \\
(0.0980)\end{array}$ & $\begin{array}{c}-0.0298 \\
(0.103)\end{array}$ & $\begin{array}{c}0.0249 \\
(0.0954)\end{array}$ \\
\hline State Population $>65(\%)$ & $\begin{array}{c}0.106 \\
(0.145)\end{array}$ & $\begin{array}{c}-0.00461 \\
(0.146)\end{array}$ & $\begin{array}{l}-0.0369 \\
(0.0950)\end{array}$ & $\begin{array}{c}-0.00338 \\
(0.102)\end{array}$ & $\begin{array}{c}-0.0874 \\
(0.0796)\end{array}$ \\
\hline State Population $<18(\%)$ & $\begin{array}{c}0.213 \\
(0.203)\end{array}$ & $\begin{array}{c}0.123 \\
(0.188)\end{array}$ & $\begin{array}{l}0.0243 \\
(0.155)\end{array}$ & $\begin{array}{l}0.0419 \\
(0.156)\end{array}$ & $\begin{array}{c}-0.0432 \\
(0.133)\end{array}$ \\
\hline GDP per capita growth (first lag) & $\begin{array}{c}-0.435 * * * \\
(0.0579)\end{array}$ & $\begin{array}{c}-0.474 * * * \\
(0.0556)\end{array}$ & $\begin{array}{c}-0.388 * * * \\
(0.0463)\end{array}$ & $\begin{array}{c}-0.394 * * * \\
(0.0504)\end{array}$ & $\begin{array}{c}-0.379 * * * \\
(0.0464)\end{array}$ \\
\hline GDP per capita growth (second lag) & $\begin{array}{c}-0.290 * * * \\
(0.0331)\end{array}$ & $\begin{array}{c}-0.325 * * * \\
(0.0323)\end{array}$ & $\begin{array}{c}-0.263 * * * \\
(0.0274)\end{array}$ & $\begin{array}{c}-0.260 * * * \\
(0.0309)\end{array}$ & $\begin{array}{c}-0.251 * * * \\
(0.0281)\end{array}$ \\
\hline $\begin{array}{l}\text { Observations } \\
\text { Number of state } \\
\text { Robust standard errors in parentheses } \\
* * * \mathrm{p}<0.01, * * \mathrm{p}<0.05, * \mathrm{p}<0.1\end{array}$ & $\begin{array}{c}864 \\
48\end{array}$ & $\begin{array}{c}864 \\
48\end{array}$ & $\begin{array}{c}864 \\
48\end{array}$ & $\begin{array}{c}864 \\
48\end{array}$ & $\begin{array}{c}864 \\
48\end{array}$ \\
\hline
\end{tabular}




\begin{tabular}{|c|c|c|c|}
\hline & (i) & (ii) & (iii) \\
\hline Health Insurance Coverage $<18$ & $\begin{array}{c}-0.0414 \\
(0.0381)\end{array}$ & & \\
\hline Health Insurance Coverage 18-65 & $\begin{array}{l}0.129 * * \\
(0.0575)\end{array}$ & & \\
\hline Private Coverage $<18$ & & $\begin{array}{c}0.00114 \\
(0.0245)\end{array}$ & $\begin{array}{c}-0.0133 \\
(0.0221)\end{array}$ \\
\hline Government Coverage $<18$ & & $\begin{array}{c}-0.0105 \\
(0.0302)\end{array}$ & $\begin{array}{c}-0.0179 \\
(0.0248)\end{array}$ \\
\hline Private Coverage $18-65$ & & $\begin{array}{c}0.0113 \\
(0.0373)\end{array}$ & $\begin{array}{c}0.0124 \\
(0.0376)\end{array}$ \\
\hline Government Coverage 18-65 & & $\begin{array}{c}0.200 * * * \\
(0.0627)\end{array}$ & \\
\hline Medicaid Coverage 18-65 & & & $\begin{array}{c}0.195 * * * \\
(0.0615)\end{array}$ \\
\hline Medicare Coverage 18-65 & & & $\begin{array}{c}0.208 * * * \\
(0.0551)\end{array}$ \\
\hline Military Coverage 18-65 & & & $\begin{array}{c}0.0660 \\
(0.0617)\end{array}$ \\
\hline State Unemployment Rate & $\begin{array}{c}-0.796^{* * *} \\
(0.166)\end{array}$ & $\begin{array}{c}-0.692^{* * *} \\
(0.115)\end{array}$ & $\begin{array}{c}-0.741 * * * \\
(0.107)\end{array}$ \\
\hline Employment/Population Ratio & $\begin{array}{c}-0.680 * * * \\
(0.160)\end{array}$ & $\begin{array}{c}-0.515 * * * \\
(0.131)\end{array}$ & $\begin{array}{c}-0.440 * * * \\
(0.116)\end{array}$ \\
\hline US Recession Dummy & $\begin{array}{c}-0.363^{*} \\
(0.186)\end{array}$ & $\begin{array}{c}-0.498 * * * \\
(0.164)\end{array}$ & $\begin{array}{c}-0.464 * * * \\
(0.152)\end{array}$ \\
\hline US GDP per capita growth rate & $\begin{array}{c}0.173 * * * \\
(0.0455)\end{array}$ & $\begin{array}{c}0.146 * * * \\
(0.0399)\end{array}$ & $\begin{array}{c}0.166 * * * \\
(0.0323)\end{array}$ \\
\hline US Unemployment Rate & $\begin{array}{c}-0.464 * * * \\
(0.155)\end{array}$ & $\begin{array}{c}-0.395 * * * \\
(0.127)\end{array}$ & $\begin{array}{c}-0.277 * * \\
(0.123)\end{array}$ \\
\hline (Log) State GDP per capita & $\begin{array}{l}-9.248^{*} \\
(5.150)\end{array}$ & $\begin{array}{l}-5.731^{*} \\
(3.226)\end{array}$ & $\begin{array}{c}-6.629 * * \\
(3.248)\end{array}$ \\
\hline Economic Freedom Index & $\begin{array}{c}2.850 * * * \\
(0.915)\end{array}$ & $\begin{array}{c}2.276 * * * \\
(0.699)\end{array}$ & $\begin{array}{c}2.433 * * * \\
(0.619)\end{array}$ \\
\hline Average State Tax Rate & $\begin{array}{c}2.596 * * * \\
(0.418)\end{array}$ & $\begin{array}{c}2.053 * * * \\
(0.280)\end{array}$ & $\begin{array}{c}2.063 * * * \\
(0.268)\end{array}$ \\
\hline (Log) State Total Spending & $\begin{array}{c}12.73 * * * \\
(3.463)\end{array}$ & $\begin{array}{c}8.482 * * * \\
(2.333)\end{array}$ & $\begin{array}{c}8.284 * * * \\
(2.090)\end{array}$ \\
\hline (Log) State Capital Spending & $\begin{array}{l}-2.294 * \\
(1.226)\end{array}$ & $\begin{array}{c}-1.757 * * \\
(0.731)\end{array}$ & $\begin{array}{c}-1.410 * * \\
(0.623)\end{array}$ \\
\hline (Log) State Education Spending & $\begin{array}{c}2.586 \\
(2.152)\end{array}$ & $\begin{array}{c}1.566 \\
(1.884)\end{array}$ & $\begin{array}{c}0.925 \\
(1.715)\end{array}$ \\
\hline (Log) State Health and Hosp. Spending & $\begin{array}{c}-1.835 * * \\
(0.852)\end{array}$ & $\begin{array}{c}-1.297 * * \\
(0.661)\end{array}$ & $\begin{array}{c}-1.999 * * * \\
(0.574)\end{array}$ \\
\hline (Log) State Highway Spending & $\begin{array}{l}-0.116 \\
(1.072)\end{array}$ & $\begin{array}{c}-0.501 \\
(0.748)\end{array}$ & $\begin{array}{l}-0.977 \\
(0.706)\end{array}$ \\
\hline (Log) State Police \& Fire Spending & $\begin{array}{l}-0.985 \\
(0.794)\end{array}$ & $\begin{array}{c}-1.413 * * * \\
(0.538)\end{array}$ & $\begin{array}{c}-1.113 * * \\
(0.493)\end{array}$ \\
\hline State Poverty Rate & $0.142 *$ & -0.00462 & -0.00121 \\
\hline
\end{tabular}


State Sponsored Health Insurance and Economic Growth

\begin{tabular}{|c|c|c|c|}
\hline & $(0.0761)$ & $(0.0633)$ & $(0.0534)$ \\
\hline \multirow[t]{2}{*}{ State Black Population (\%) } & 0.0546 & -0.00616 & 0.00126 \\
\hline & $(0.124)$ & $(0.0944)$ & $(0.0859)$ \\
\hline \multirow[t]{2}{*}{ State Hispanic Population (\%) } & -0.182 & -0.185 & -0.112 \\
\hline & $(0.178)$ & $(0.123)$ & $(0.109)$ \\
\hline \multirow[t]{2}{*}{ State High School Grads (\%) } & -0.0861 & -0.0735 & $-0.0971 * *$ \\
\hline & $(0.0631)$ & $(0.0510)$ & $(0.0490)$ \\
\hline \multirow[t]{2}{*}{ State College Grads (\%) } & -0.0968 & $-0.100 *$ & -0.0600 \\
\hline & $(0.0807)$ & $(0.0539)$ & $(0.0454)$ \\
\hline \multirow[t]{2}{*}{ State Population Growth } & $0.291 * * *$ & $0.289 * * *$ & $0.293 * * *$ \\
\hline & $(0.0582)$ & $(0.0524)$ & $(0.0487)$ \\
\hline \multirow[t]{2}{*}{ State Population $>65(\%)$} & -0.120 & $-0.143 * * *$ & $-0.155^{* * *}$ \\
\hline & $(0.0814)$ & $(0.0491)$ & $(0.0439)$ \\
\hline \multirow[t]{2}{*}{ State Population $<18(\%)$} & -0.107 & $-0.150 * *$ & $-0.173 * * *$ \\
\hline & $(0.113)$ & $(0.0725)$ & $(0.0642)$ \\
\hline \multirow[t]{2}{*}{ GDP per capita growth } & $0.146^{* * * *}$ & $0.148^{* * *} *$ & $0.135^{* * *} *$ \\
\hline & $(0.0409)$ & $(0.0368)$ & $(0.0326)$ \\
\hline \multirow[t]{2}{*}{ GDP per capita growth (first lag) } & $0.101 * * *$ & $0.0962 * * *$ & $0.0875 * * *$ \\
\hline & $(0.0339)$ & $(0.0334)$ & $(0.0310)$ \\
\hline \multirow[t]{2}{*}{ GDP per capita growth (second lag) } & 0.0204 & 0.00946 & -0.00252 \\
\hline & $(0.0218)$ & $(0.0214)$ & $(0.0200)$ \\
\hline Observations & 960 & 960 & 952 \\
\hline Number of state & 48 & 48 & 48 \\
\hline $\begin{array}{l}\text { Robust standard errors in parentheses } \\
* * * p<0.01, * * p<0.05, * p<0.1\end{array}$ & & & \\
\hline
\end{tabular}




\begin{tabular}{|c|c|c|c|c|c|}
\hline \multicolumn{6}{|c|}{$\begin{array}{l}\text { Table 6: Effects of Health Insurance Coverage and S } \\
\text { States, 1988-2010) } \\
\text { Dependent Variable = Total Employment Growth }(\%)\end{array}$} \\
\hline & (i) & (ii) & (iii) & (iv) & (v) \\
\hline Health Insurance Coverage $<18$ & $\begin{array}{c}-0.0688^{*} \\
(0.0374)\end{array}$ & $\begin{array}{c}-0.0655^{*} \\
(0.0368)\end{array}$ & & & \\
\hline Health Insurance Coverage 18-65 & $\begin{array}{c}0.105 \\
(0.0645)\end{array}$ & $\begin{array}{c}0.0780 \\
(0.0570)\end{array}$ & & & \\
\hline Private Coverage $<18$ & & & $\begin{array}{l}0.00232 \\
(0.0281)\end{array}$ & $\begin{array}{l}0.00902 \\
(0.0260)\end{array}$ & $\begin{array}{l}-0.0124 \\
(0.0221)\end{array}$ \\
\hline Government Coverage $<18$ & & & $\begin{array}{l}-0.0222 \\
(0.0291)\end{array}$ & $\begin{array}{r}-0.00982 \\
(0.0261)\end{array}$ & $\begin{array}{l}-0.0388 \\
(0.0237)\end{array}$ \\
\hline Private Coverage $18-65$ & & & $\begin{array}{l}-0.0228 \\
(0.0420)\end{array}$ & $\begin{array}{l}-0.0468 \\
(0.0368)\end{array}$ & $\begin{array}{l}-0.0375 \\
(0.0301)\end{array}$ \\
\hline Government Coverage 18-65 & & & $\begin{array}{c}0.171^{* * * *} \\
(0.0542)\end{array}$ & $\begin{array}{c}0.163 * * * \\
(0.0495)\end{array}$ & \\
\hline Medicaid Coverage 18-65 & & & & & $\begin{array}{l}0.107 * * \\
(0.0533)\end{array}$ \\
\hline Medicare Coverage 18-65 & & & & & $\begin{array}{c}0.0808 \\
(0.0523)\end{array}$ \\
\hline Military Coverage 18-65 & & & & & $\begin{array}{c}0.106 \\
(0.0650)\end{array}$ \\
\hline Personal Healthcare Spending (\% GDP) & $\begin{array}{c}0.461 \\
(0.300)\end{array}$ & & $\begin{array}{c}0.147 \\
(0.239)\end{array}$ & & $\begin{array}{c}-0.501 * \\
(0.278)\end{array}$ \\
\hline Medicare Spending (\% GDP) & $\begin{array}{r}-0.0789 \\
(0.382)\end{array}$ & & $\begin{array}{c}-0.0162 \\
(0.303)\end{array}$ & & $\begin{array}{c}0.580 \\
(0.847)\end{array}$ \\
\hline Medicaid Spending (\% GDP) & $\begin{array}{l}0.0339 \\
(0.598)\end{array}$ & & $\begin{array}{l}-0.400 \\
(0.512)\end{array}$ & & $\begin{array}{c}1.150 * * \\
(0.556)\end{array}$ \\
\hline (Log) Real Personal Spending per capita & & $\begin{array}{c}7.603 * * * \\
(2.771)\end{array}$ & & $\begin{array}{c}5.682 * * \\
(2.244)\end{array}$ & $\begin{array}{c}9.986 * * * * \\
(3.323)\end{array}$ \\
\hline (Log) Real Medicare Spending per enrollee & & $\begin{array}{l}-0.879 \\
(1.046)\end{array}$ & & $\begin{array}{c}-0.331 \\
(0.928)\end{array}$ & $\begin{array}{l}-1.008 \\
(2.965)\end{array}$ \\
\hline (Log) Real Medicaid Spending per enrollee & & $\begin{array}{c}-2.354 * * \\
(0.963)\end{array}$ & & $\begin{array}{c}-2.720 * * * \\
(1.014)\end{array}$ & $\begin{array}{c}-3.887 * * * \\
(1.076)\end{array}$ \\
\hline State Unemployment Rate & $\begin{array}{c}-0.897 * * * \\
(0.146)\end{array}$ & $\begin{array}{c}-0.794 * * * \\
(0.148)\end{array}$ & $\begin{array}{c}-0.719 * * * \\
(0.128)\end{array}$ & $\begin{array}{c}-0.679 * * * \\
(0.123)\end{array}$ & $\begin{array}{c}-0.680 * * * \\
(0.126)\end{array}$ \\
\hline Employment/Population Ratio & $\begin{array}{c}-0.435 * * \\
(0.207)\end{array}$ & $\begin{array}{c}-0.310^{*} \\
(0.159)\end{array}$ & $\begin{array}{l}-0.254 \\
(0.165)\end{array}$ & $\begin{array}{c}-0.212 \\
(0.129)\end{array}$ & $\begin{array}{l}-0.101 \\
(0.107)\end{array}$ \\
\hline US Recession Dummy & $\begin{array}{c}-0.460 * * * \\
(0.174)\end{array}$ & $\begin{array}{c}-0.423 * * \\
(0.171)\end{array}$ & $\begin{array}{c}-0.692 * * * \\
(0.164)\end{array}$ & $\begin{array}{c}-0.549 * * * \\
(0.165)\end{array}$ & $\begin{array}{c}-0.584 * * * \\
(0.157)\end{array}$ \\
\hline US GDP per capita growth rate & $\begin{array}{l}0.115^{* *} \\
(0.0570)\end{array}$ & $\begin{array}{c}0.167 * * * \\
(0.0535)\end{array}$ & $\begin{array}{c}0.0586 \\
(0.0498)\end{array}$ & $\begin{array}{l}0.117 * * \\
(0.0470)\end{array}$ & $\begin{array}{c}0.124 * * * * \\
(0.0473)\end{array}$ \\
\hline US Unemployment Rate & $\begin{array}{c}-0.288^{* *} \\
(0.131)\end{array}$ & $\begin{array}{c}-0.260 * * \\
(0.127)\end{array}$ & $\begin{array}{c}-0.312 * * \\
(0.131)\end{array}$ & $\begin{array}{c}-0.349 * * * \\
(0.113)\end{array}$ & $\begin{array}{c}-0.235^{* *} \\
(0.101)\end{array}$ \\
\hline (Log) State GDP per capita & $\begin{array}{l}-3.556 \\
(4.319)\end{array}$ & $\begin{array}{c}-9.069 * * \\
(4.509)\end{array}$ & $\begin{array}{l}-4.100 \\
(3.397)\end{array}$ & $\begin{array}{c}-6.906 * * \\
(3.216)\end{array}$ & $\begin{array}{c}-8.144 * * * \\
(2.797)\end{array}$ \\
\hline Economic Freedom Index & $\begin{array}{c}2.965 * * * \\
(0.877)\end{array}$ & $\begin{array}{c}1.854 * * \\
(0.779)\end{array}$ & $\begin{array}{c}2.313 * * * \\
(0.766)\end{array}$ & $\begin{array}{l}1.305^{*} \\
(0.726)\end{array}$ & $\begin{array}{c}0.936 \\
(0.596)\end{array}$ \\
\hline Average State Tax Rate & $\begin{array}{c}2.457 * * * \\
(0.415)\end{array}$ & $\begin{array}{c}1.975 * * * \\
(0.353)\end{array}$ & $\begin{array}{c}2.325 * * * \\
(0.318)\end{array}$ & $\begin{array}{c}1.759 * * * \\
(0.239)\end{array}$ & $\begin{array}{c}1.451^{* * *} * \\
(0.278)\end{array}$ \\
\hline
\end{tabular}


State Sponsored Health Insurance and Economic Growth

\begin{tabular}{|c|c|c|c|c|c|}
\hline (Log) State Total Spending & $\begin{array}{c}13.08 * * * \\
(2.603)\end{array}$ & $\begin{array}{c}12.11^{* * * *} \\
(2.553)\end{array}$ & $\begin{array}{c}12.26 \text { *** } \\
(2.376)\end{array}$ & $\begin{array}{c}10.98 * * * \\
(2.332)\end{array}$ & $\begin{array}{c}8.319 * * * \\
(1.817)\end{array}$ \\
\hline (Log) State Capital Spending & $\begin{array}{l}-1.701 \\
(1.060)\end{array}$ & $\begin{array}{c}-1.516^{*} \\
(0.807)\end{array}$ & $\begin{array}{c}-1.629 * * \\
(0.710)\end{array}$ & $\begin{array}{l}-0.896 \\
(0.650)\end{array}$ & $\begin{array}{c}-0.592 \\
(0.592)\end{array}$ \\
\hline (Log) State Education Spending & $\begin{array}{l}-3.971 * \\
(2.310)\end{array}$ & $\begin{array}{l}-1.879 \\
(1.879)\end{array}$ & $\begin{array}{l}-2.711 \\
(1.738)\end{array}$ & $\begin{array}{c}-3.430 * * \\
(1.611)\end{array}$ & $\begin{array}{c}-3.243^{* *} \\
(1.513)\end{array}$ \\
\hline (Log) State Health and Hosp. Spending & $\begin{array}{c}-1.312 * * \\
(0.591)\end{array}$ & $\begin{array}{c}-1.089^{*} \\
(0.636)\end{array}$ & $\begin{array}{c}-1.458 * * * \\
(0.543)\end{array}$ & $\begin{array}{c}-1.157 * * \\
(0.544)\end{array}$ & $\begin{array}{c}-1.063^{* *} \\
(0.466)\end{array}$ \\
\hline (Log) State Highway Spending & $\begin{array}{c}-1.462 \\
(1.007)\end{array}$ & $\begin{array}{l}-1.087 \\
(0.731)\end{array}$ & $\begin{array}{c}-1.511 * * \\
(0.641)\end{array}$ & $\begin{array}{c}-1.216^{*} \\
(0.640)\end{array}$ & $\begin{array}{c}-1.421 * * \\
(0.712)\end{array}$ \\
\hline (Log) State Police \& Fire Spending & $\begin{array}{c}-2.091 * * \\
(0.817)\end{array}$ & $\begin{array}{c}-1.708 * * * \\
(0.659)\end{array}$ & $\begin{array}{c}-1.669 * * * \\
(0.516)\end{array}$ & $\begin{array}{c}-1.262 * * * \\
(0.477)\end{array}$ & $\begin{array}{c}-0.920 * * \\
(0.445)\end{array}$ \\
\hline State Poverty Rate & $\begin{array}{l}0.154 * * \\
(0.0698)\end{array}$ & $\begin{array}{l}0.136 * * \\
(0.0616)\end{array}$ & $\begin{array}{c}0.0422 \\
(0.0537)\end{array}$ & $\begin{array}{l}0.00768 \\
(0.0579)\end{array}$ & $\begin{array}{c}0.0323 \\
(0.0519)\end{array}$ \\
\hline State Black Population (\%) & $\begin{array}{c}0.129 \\
(0.112)\end{array}$ & $\begin{array}{l}0.0615 \\
(0.103)\end{array}$ & $\begin{array}{l}0.0841 \\
(0.103)\end{array}$ & $\begin{array}{c}0.0202 \\
(0.0926)\end{array}$ & $\begin{array}{c}0.0290 \\
(0.0965)\end{array}$ \\
\hline State Hispanic Population (\%) & $\begin{array}{c}-0.0728 \\
(0.150)\end{array}$ & $\begin{array}{l}-0.114 \\
(0.143)\end{array}$ & $\begin{array}{c}-0.0952 \\
(0.119)\end{array}$ & $\begin{array}{l}-0.128 \\
(0.105)\end{array}$ & $\begin{array}{r}-0.0717 \\
(0.105)\end{array}$ \\
\hline State High School Grads (\%) & $\begin{array}{l}-0.115^{*} \\
(0.0611)\end{array}$ & $\begin{array}{c}-0.0916 \\
(0.0599)\end{array}$ & $\begin{array}{l}-0.121 * * \\
(0.0603)\end{array}$ & $\begin{array}{l}-0.137 * * \\
(0.0557)\end{array}$ & $\begin{array}{l}-0.122 * * \\
(0.0535)\end{array}$ \\
\hline State College Grads (\%) & $\begin{array}{c}-0.117 \\
(0.0785)\end{array}$ & $\begin{array}{l}-0.0789 \\
(0.0845)\end{array}$ & $\begin{array}{c}-0.0508 \\
(0.0623)\end{array}$ & $\begin{array}{c}-0.0415 \\
(0.0624)\end{array}$ & $\begin{array}{l}-0.0387 \\
(0.0424)\end{array}$ \\
\hline State Population Growth & $\begin{array}{c}0.370 * * * \\
(0.0602)\end{array}$ & $\begin{array}{c}0.350 * * * \\
(0.0496)\end{array}$ & $\begin{array}{c}0.347 * * * \\
(0.0516)\end{array}$ & $\begin{array}{c}0.341 * * * \\
(0.0492)\end{array}$ & $\begin{array}{c}0.359 * * * \\
(0.0506)\end{array}$ \\
\hline State Population > $65(\%)$ & $\begin{array}{l}-0.124 * \\
(0.0679)\end{array}$ & $\begin{array}{l}-0.0926 \\
(0.0710)\end{array}$ & $\begin{array}{c}-0.152 * * * \\
(0.0543)\end{array}$ & $\begin{array}{c}-0.0992 * * \\
(0.0490)\end{array}$ & $\begin{array}{c}-0.132 * * * \\
(0.0445)\end{array}$ \\
\hline State Population < $18(\%)$ & $\begin{array}{l}-0.0458 \\
(0.0933)\end{array}$ & $\begin{array}{c}-0.0382 \\
(0.0980)\end{array}$ & $\begin{array}{c}-0.115 \\
(0.0757)\end{array}$ & $\begin{array}{l}-0.0258 \\
(0.0726)\end{array}$ & $\begin{array}{l}-0.0690 \\
(0.0575)\end{array}$ \\
\hline GDP per capita growth & $\begin{array}{c}0.107 * * * \\
(0.0345)\end{array}$ & $\begin{array}{c}0.144 * * * \\
(0.0332)\end{array}$ & $\begin{array}{c}0.143 * * * \\
(0.0350)\end{array}$ & $\begin{array}{c}0.160 * * * \\
(0.0299)\end{array}$ & $\begin{array}{c}0.142 * * * \\
(0.0266)\end{array}$ \\
\hline GDP per capita growth (first lag) & $\begin{array}{c}0.0703 * * \\
(0.0342)\end{array}$ & $\begin{array}{c}0.110 * * * \\
(0.0331)\end{array}$ & $\begin{array}{c}0.0932 * * * \\
(0.0339)\end{array}$ & $\begin{array}{c}0.120 * * * \\
(0.0328)\end{array}$ & $\begin{array}{c}0.111^{* * * *} \\
(0.0304)\end{array}$ \\
\hline GDP per capita growth (second lag) & $\begin{array}{l}-0.0220 \\
(0.0214)\end{array}$ & $\begin{array}{l}0.00468 \\
(0.0207)\end{array}$ & $\begin{array}{l}-0.0147 \\
(0.0218)\end{array}$ & $\begin{array}{l}0.00720 \\
(0.0201)\end{array}$ & $\begin{array}{l}-0.0131 \\
(0.0186)\end{array}$ \\
\hline Observations & 864 & 864 & 864 & 864 & 858 \\
\hline $\begin{array}{l}\text { Number of state } \\
\text { Standard errors in parentheses } \\
* * * \mathrm{p}<0.01, * * \mathrm{p}<0.05, * \mathrm{p}<0.1\end{array}$ & 48 & 48 & 48 & 48 & 48 \\
\hline
\end{tabular}


Table 7: Effects of Health Insurance Coverage and Spending on Country GDP Growth (OECD Sample, Spanning Years 2000-2011)

Dependent Variable $=$ Country Real GDP per capita Growth

\begin{tabular}{|c|c|c|c|}
\hline & (i) & (ii) & (iii) \\
\hline Health Insurance Coverage ( $\%$ of Population) & $\begin{array}{l}0.354^{*} \\
(0.196)\end{array}$ & & \\
\hline Public Health Insurance Coverage (\% of Population) & & $\begin{array}{c}0.0509 \\
(0.0345)\end{array}$ & $\begin{array}{c}0.136 \\
(0.174)\end{array}$ \\
\hline $\begin{array}{l}\text { Private Health Insurance Coverage (\% of } \\
\text { Population) }\end{array}$ & & 0.0815 & 0.0394 \\
\hline Total Healthcare Cost (\% of GDP) & $\begin{array}{l}-1.127 \\
(0.717)\end{array}$ & $\begin{array}{c}(0.0791) \\
-1.627 * * \\
(0.678)\end{array}$ & $(0.0638)$ \\
\hline Public Healthcare Cost (\% of GDP) & & & $\begin{array}{c}1.034 * * * \\
(0.271)\end{array}$ \\
\hline Private Healthcare Cost ( $\%$ of GDP) & & & $\begin{array}{c}0.595 \\
(1.132)\end{array}$ \\
\hline (Log) Real GDP per capita & $\begin{array}{c}22.05 * * \\
(9.606)\end{array}$ & $\begin{array}{c}15.78 \\
(10.39)\end{array}$ & $\begin{array}{l}25.85^{*} \\
(13.84)\end{array}$ \\
\hline Capital Formation (\% of GDP) & $\begin{array}{c}0.429 * * * \\
(0.159)\end{array}$ & $\begin{array}{c}0.325 \\
(0.225)\end{array}$ & $\begin{array}{c}0.205 \\
(0.181)\end{array}$ \\
\hline Tax Revenue (\% of GDP) & $\begin{array}{c}0.00402 \\
(0.157)\end{array}$ & $\begin{array}{c}-0.00160 \\
(0.174)\end{array}$ & $\begin{array}{c}0.118 \\
(0.188)\end{array}$ \\
\hline Economic Freedom Index & $\begin{array}{l}-1.650 \\
(1.137)\end{array}$ & $\begin{array}{c}-0.541 \\
(1.075)\end{array}$ & $\begin{array}{c}0.299 \\
(0.915)\end{array}$ \\
\hline Population Growth Rate & $\begin{array}{l}-0.300 \\
(0.266)\end{array}$ & $\begin{array}{l}-0.421 \\
(0.387)\end{array}$ & $\begin{array}{l}-0.255 \\
(0.454)\end{array}$ \\
\hline Population Under 15 (Percent) & $\begin{array}{c}1.343 \\
(1.112)\end{array}$ & $\begin{array}{c}0.386 \\
(1.097)\end{array}$ & $\begin{array}{l}2.400^{*} \\
(1.276)\end{array}$ \\
\hline Population Over 65 (Percent) & $\begin{array}{c}1.174 \\
(0.790)\end{array}$ & $\begin{array}{c}0.796 \\
(0.748)\end{array}$ & $\begin{array}{c}1.449 * * \\
(0.582)\end{array}$ \\
\hline Unemployment Rate & $\begin{array}{c}-0.367 * * \\
(0.167)\end{array}$ & $\begin{array}{c}-0.385^{* * *} \\
(0.117)\end{array}$ & $\begin{array}{c}-0.357^{*} \\
(0.200)\end{array}$ \\
\hline Employment-Population Ratio & $\begin{array}{c}-1.298 * * * \\
(0.341)\end{array}$ & $\begin{array}{c}-0.974 * * \\
(0.399)\end{array}$ & $\begin{array}{c}-0.544 \\
(0.341)\end{array}$ \\
\hline Total OECD Real GDP growth rate & $\begin{array}{c}0.655^{* * *} * \\
(0.150)\end{array}$ & $\begin{array}{c}0.619 * * * \\
(0.152)\end{array}$ & $\begin{array}{c}0.530 \text { *** } \\
(0.150)\end{array}$ \\
\hline Short-term interest rate & $\begin{array}{c}-0.0188 \\
(0.152)\end{array}$ & $\begin{array}{c}-0.177 \\
(0.162)\end{array}$ & $\begin{array}{l}-0.143 \\
(0.169)\end{array}$ \\
\hline Long-term interest rate & $\begin{array}{c}-0.224 \\
(0.351)\end{array}$ & $\begin{array}{l}-0.107 \\
(0.352)\end{array}$ & $\begin{array}{c}0.208 \\
(0.338)\end{array}$ \\
\hline Real GDP per capital Growth (first lag) & $\begin{array}{l}-0.0376 \\
(0.0932)\end{array}$ & $\begin{array}{c}-0.0205 \\
(0.145)\end{array}$ & $\begin{array}{c}-0.126 \\
(0.117)\end{array}$ \\
\hline Real GDP per capital Growth (second lag) & $\begin{array}{c}-0.108 \\
(0.0715) \\
\end{array}$ & $\begin{array}{c}-0.112 \\
(0.0786) \\
\end{array}$ & $\begin{array}{c}-0.198 * * \\
(0.0850) \\
\end{array}$ \\
\hline $\begin{array}{l}\text { Observations } \\
\text { Number of countries } \\
\text { Robust standard errors in parentheses } \\
* * * \mathrm{p}<0.01, * * \mathrm{p}<0.05, * \mathrm{p}<0.1\end{array}$ & $\begin{array}{c}247 \\
28\end{array}$ & $\begin{array}{c}171 \\
21\end{array}$ & $\begin{array}{c}164 \\
20\end{array}$ \\
\hline
\end{tabular}


State Sponsored Health Insurance and Economic Growth 
Table 8: Effects of Health Insurance Coverage and Spending on Country Employment Growth, (OECD Sample, Spanning Years 2000-2011)

Dependent Variable $=$ Country Total Employment Growth

\begin{tabular}{|c|c|c|c|}
\hline & (i) & (ii) & (iii) \\
\hline Health Insurance Coverage (\% of Population) & $\begin{array}{l}0.250^{*} \\
(0.150)\end{array}$ & & \\
\hline Public Health Insurance Coverage ( $\%$ of Population) & & $\begin{array}{c}0.0910 \\
(0.0690)\end{array}$ & $\begin{array}{c}0.362^{* * *} \\
(0.106)\end{array}$ \\
\hline Private Health Insurance Coverage ( $\%$ of Population) & & $\begin{array}{c}0.0449 \\
(0.0291)\end{array}$ & $\begin{array}{c}0.0685^{* * *} \\
(0.0271)\end{array}$ \\
\hline Total Healthcare Cost (\% of GDP) & $\begin{array}{l}0.535^{*} \\
(0.324)\end{array}$ & $\begin{array}{c}-0.0990 \\
(0.444)\end{array}$ & \\
\hline Public Healthcare Cost (\% of GDP) & & & $\begin{array}{l}0.363^{*} \\
(0.203)\end{array}$ \\
\hline Private Healthcare Cost (\% of GDP) & & & $\begin{array}{l}-0.924 * \\
(0.559)\end{array}$ \\
\hline (Log) Real GDP per capita & $\begin{array}{l}-5.314 \\
(5.377)\end{array}$ & $\begin{array}{l}-8.145 \\
(6.697)\end{array}$ & $\begin{array}{l}-2.763 \\
(6.086)\end{array}$ \\
\hline Capital Formation ( $\%$ of GDP) & $\begin{array}{l}0.0684 \\
(0.218)\end{array}$ & $\begin{array}{l}-0.176 \\
(0.142)\end{array}$ & $\begin{array}{l}-0.144 \\
(0.111)\end{array}$ \\
\hline Tax Revenue (\% of GDP) & $\begin{array}{c}0.128 \\
(0.132)\end{array}$ & $\begin{array}{l}-0.167 \\
(0.114)\end{array}$ & $\begin{array}{l}-0.0987 \\
(0.0876)\end{array}$ \\
\hline Economic Freedom Index & $\begin{array}{l}0.0670 \\
(0.752)\end{array}$ & $\begin{array}{l}-0.0859 \\
(0.612)\end{array}$ & $\begin{array}{c}0.562 \\
(0.629)\end{array}$ \\
\hline Population Growth Rate & $\begin{array}{c}0.474 * * \\
(0.225)\end{array}$ & $\begin{array}{c}0.418 \\
(0.272)\end{array}$ & $\begin{array}{l}0.436^{* * *} \\
(0.203)\end{array}$ \\
\hline Population Under 15 (Percent) & $\begin{array}{c}0.241 \\
(0.915)\end{array}$ & $\begin{array}{l}-0.754 \\
(1.008)\end{array}$ & $\begin{array}{l}-0.524 \\
(0.540)\end{array}$ \\
\hline Population Over 65 (Percent) & $\begin{array}{c}0.433 \\
(0.433)\end{array}$ & $\begin{array}{l}-0.782 \\
(0.481)\end{array}$ & $\begin{array}{l}-0.484^{*} \\
(0.275)\end{array}$ \\
\hline Unemployment Rate & $\begin{array}{l}-0.0856 \\
(0.112)\end{array}$ & $\begin{array}{l}-0.0383 \\
(0.0730)\end{array}$ & $\begin{array}{l}-0.0144 \\
(0.0699)\end{array}$ \\
\hline Employment-Population Ratio & $\begin{array}{c}0.273 \\
(0.246)\end{array}$ & $\begin{array}{c}0.755^{* * * *} \\
(0.164)\end{array}$ & $\begin{array}{c}0.766^{* * * *} \\
(0.118)\end{array}$ \\
\hline Total OECD Real GDP growth rate & $\begin{array}{c}0.238 * * * \\
(0.0909)\end{array}$ & $\begin{array}{c}0.254 * * * \\
(0.0595)\end{array}$ & $\begin{array}{c}0.252 * * * \\
(0.0371)\end{array}$ \\
\hline Short-term interest rate & $\begin{array}{l}0.0621 \\
(0.148)\end{array}$ & $\begin{array}{c}-0.0294 \\
(0.110)\end{array}$ & $\begin{array}{c}-0.110 \\
(0.0746)\end{array}$ \\
\hline Long-term interest rate & $\begin{array}{l}-0.223 \\
(0.236)\end{array}$ & $\begin{array}{c}-0.332 \\
(0.225)\end{array}$ & $\begin{array}{l}-0.134 \\
(0.203)\end{array}$ \\
\hline Real GDP per capital Growth & $\begin{array}{c}0.223 * * * \\
(0.0762)\end{array}$ & $\begin{array}{c}0.330 * * * \\
(0.0580)\end{array}$ & $\begin{array}{c}0.223 * * * \\
(0.0559)\end{array}$ \\
\hline Real GDP per capital Growth (first lag) & $\begin{array}{c}0.276 * * * \\
(0.0781)\end{array}$ & $\begin{array}{c}0.379 * * * \\
(0.0676)\end{array}$ & $\begin{array}{c}0.284 * * * \\
(0.0655)\end{array}$ \\
\hline Real GDP per capital Growth (second lag) & $\begin{array}{c}0.140^{*} \\
(0.0823)\end{array}$ & $\begin{array}{l}0.0405 \\
(0.131)\end{array}$ & $\begin{array}{c}0.00666 \\
(0.115)\end{array}$ \\
\hline Observations & 171 & 134 & 127 \\
\hline Number of countries & 19 & 16 & 15 \\
\hline $\begin{array}{l}\text { Robust standard errors in parentheses } \\
* * * \mathrm{p}<0.01, * * \mathrm{p}<0.05, * \mathrm{p}<0.1\end{array}$ & & & \\
\hline
\end{tabular}


State Sponsored Health Insurance and Economic Growth 